\title{
Last interglacial climates of south-eastern Australia: plant and beetle-based reconstructions from Yarra Creek, King Island, Tasmania
}

\author{
Nick Porch ${ }^{\mathrm{a}, *}$, Gregory J. Jordan ${ }^{\mathrm{b}}$, David M. Price ${ }^{\mathrm{c}}$, Richard W. Barnes ${ }^{\mathrm{d}}$, Mike K. Macphail ${ }^{\mathrm{a}}$, \\ Mike Pemberton ${ }^{\mathrm{e}}$ \\ a Archaeology and Natural History, ANU College of Asia and the Pacific, The Australian National University, Canberra, ACT 0200 Australia \\ ${ }^{\mathrm{b}}$ School of Plant Science, University of Tasmania, Private Bag 55, Hobart, TAS 7001, Australia \\ ${ }^{\mathrm{C} S}$ School of Earth and Environmental Sciences, University of Wollongong, Wollongong, NSW 2522, Australia \\ ${ }^{\mathrm{d}}$ SEMF Consultants, Level 2, 162 Macquarie Street, Hobart, TAS 7000, Australia \\ ${ }^{\mathrm{e}}$ Department of Primary Industries, Parks, Water and Environment, P.O. Box 44, Hobart, TAS 7001, Australia
}

\section{A R T I C L E I N F O}

\section{Article history:}

Received 24 October 2008

Received in revised form

17 September 2009

Accepted 28 September 2009

\begin{abstract}
A B S T R A C T
This paper explores the palaeoclimatic significance of a fossil plant and insect record from Yarra Creek, on King Island, between Tasmania and the Australian mainland. The record dates, based upon a thermoluminescence chronology and other evidence, to Marine Isotope Stage 5 (MIS 5); the exact timing is impossible to ascertain given the resolution of the thermoluminescence results and the presence of an unconformity in the dated section. The presence of a cool-temperate rainforest flora, outside its modern range, and other independent evidence, suggest the sequence may represent the last interglacial (MIS 5e) rather than a later MIS 5 substage. Using coexistence methods that compare modern climatic ranges of the taxa in the assemblage we reconstruct independent beetle and plant based annual and seasonal temperate and precipitation parameters. The results imply the assemblage was deposited under a wetter summer climate and suggest conditions of enhanced temperature seasonality. It is probable that enhanced temperature seasonality is a methodological artefact reflecting the rarity of extremely equable climates (like King Island) in modern climate space. This would indicate a limitation of most methods of palaeoclimatic reconstruction that rely on modern datasets - it is only possible to reconstruct past climates as being within the range of values in that currently exist in modern climate space.
\end{abstract}

Crown Copyright $\odot 2009$ Published by Elsevier Ltd. All rights reserved.

\section{Introduction}

Our understanding of the nature of last interglacial and Marine Isotope Stage 5 (MIS 5) climates Australia is limited. It is based on a relatively small number of biostratigraphically dated pollen records and lake level or river flow evidence from inland Australia. Terrestrial pollen records that span this period are restricted to the mesic margins of the continent and include sites in south-eastern Australian (Singh and Geissler, 1985; Harle et al., 2004; Kershaw et al., 2007), Tasmania (Colhoun, 1980; Colhoun et al., 1982, 1989, 1999), and the Wet Tropics region of northeastern Australia (Kershaw, 1978; Moss and Kershaw, 2000;

\footnotetext{
* Corresponding author. Tel.: +612 6125 5975; fax: +6126125 4917

E-mail addresses: nicholas.porch@anu.edu.au (N. Porch), greg.jordan@utas.edu. au (G.J. Jordan), dprice@uow.edu.au (D.M. Price), richard.barnes@semf.com.au (R.W. Barnes), mike.macphail@anu.edu.au (M.K. Macphail), mike.pemberton@dpiwe.tas. gov.au (M. Pemberton).
}

Kershaw et al., 2005). Several marine records from the northern Australian coastal margins include at least part of this period (Kershaw et al., 1993; van der Kaars et al., 2000; van der Kaars et al., 2006). High lake levels in arid-zone lakes and enhanced river flow in the Murray-Darling basin during the last and previous interglacials reflect enhanced monsoon activity and therefore higher precipitation during these periods (Magee et al., 1995; Croke et al., 1996; Bowler et al., 1998; DeVogel et al., 2004; Hesse et al., 2004).

In general palaeoclimatic interpretation of last interglacial sedimentary sequences suggests that MIS 5e was wetter than the Holocene, perhaps slightly warmer. This is based, for pollen records, upon the expansion of rainforest and other mesic taxa relative to Holocene levels (Harle et al., 2004), and for lake and river records, upon higher lake levels and flows than those attained during the Holocene (Hesse et al., 2004). In relation to the pollen data, a potential difficulty emerges in basing putative increased moisture on rainforest expansion - the Holocene is characterised by extensive and intensive aboriginal occupation in contrast to the last 
interglacial when Australia was unoccupied (Harle et al., 2004; Kershaw and van der Kaars, 2007). The trend in late Quaternary palynology of the region is to suggest that Aboriginal burning, documented by increased charcoal, resulted in contraction of fire sensitive vegetation to fire-protected habitats (Singh and Geissler, 1985; van der Kaars et al., 2000; Kershaw et al., 2002; Hope et al., 2004). This has implications for interpreting the significance of last interglacial rainforest expansion - was rainforest more extensive during this period because of wetter climates or have Holocene Aboriginal and, recently, post-European fire regimes prevented extant rainforests from reaching their climatically determined extent?

This paper provides the first quantitative analysis of MIS 5 climates for the Australian region that is based on evidence other than pollen data. We describe the results of palaeoclimatic analysis of plant and insect macrofossils from the site of Yarra Creek, on King Island in the Bass Strait region of south-eastern Australia (Fig. 1). We present luminescence ages for the sequence that firmly place it in MIS 5, and although the exact timing is difficult to determine we believe a range of evidence suggests that the organic sediments were accumulated during the last interglacial (MIS 5e). We use coexistence methods of palaeoclimate reconstruction to independently reconstruct the King Islands MIS 5 climate using bioclimatic envelope data for beetle and plant taxa.

\section{Site setting and context}

\subsection{Site location}

King Island is a continental island, the largest in Bass Strait, in between Tasmania and the Australian mainland (Fig. 1); with a drop in sea level of around $20 \mathrm{~m}$ it became part of Tasmania, and with a drop of around $50 \mathrm{~m}$, it became part of greater Australia (Blom, 1988). The island is characterised by low relief with the highest point of the island, on the southern plateau, being less than $150 \mathrm{~m}$ above sea level. Lakes and swamps are common in the low-lying northern half of the island where extensive late Quaternary sandsheet and dune development has impeded drainage. Dune systems are best developed in the west and along the southern coast reflecting the prevailing westerly and south-westerly wind-flow. The sedimentary sequence described here is exposed in a sea cliff just above modern sea level, to the north of the outflow of Yarra Creek, above a small cobble beach on City of Melbourne Bay (Fig. 1). Yarra Creek is a deeply incised system that drains the southern plateau of King Island. It flows through a gorge (up to $80 \mathrm{~m}$ deep) that presently contains remnant wet eucalypt forest including several temperate rainforest species.

\subsection{Previous research}

King Island has been the focus of geomorphic and palaeoenvironmental analyses that have examined extensive continental and marine dune systems (Jennings, 1957, 1959), and several extended lake, swamp, and partly marine sequences (D'Costa et al., 1993; D'Costa, 1997). Jennings (1959) described the fossil site here referred to as 'Yarra Creek' in an overview of the geomorphology of King Island and suggested that the organic sand and peat sequence represented deltaic deposits derived from Yarra Creek. Several aspects of the site were examined superficially. A single radiocarbon determination on wood collected from the base of the deposit by Jennings returned a result of $37,500 \pm 1900$ (NZ-349), which Colhoun (1985) interpreted to reflect probable

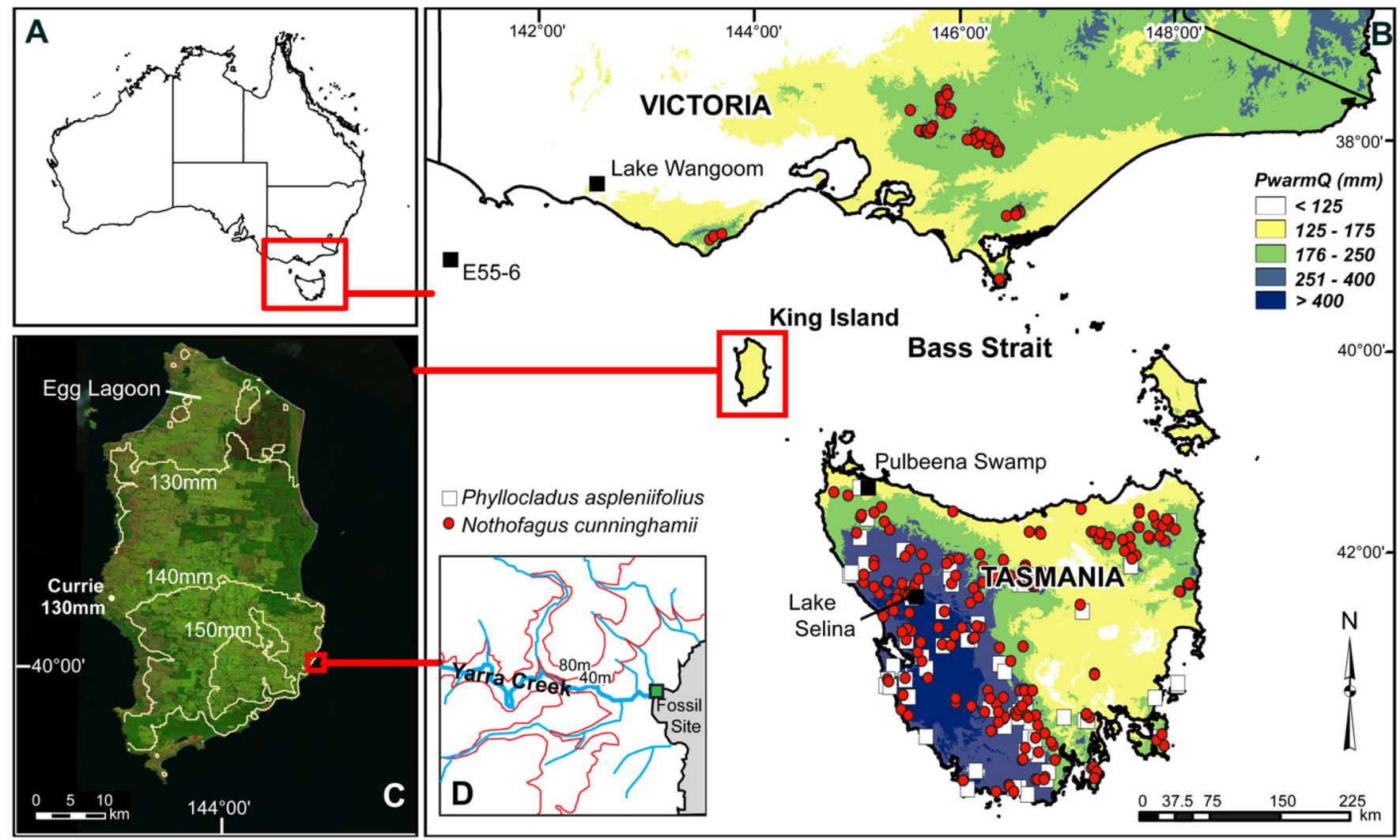

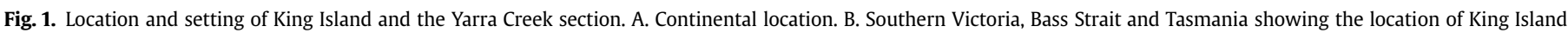

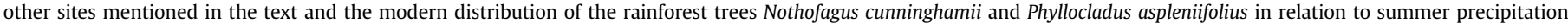

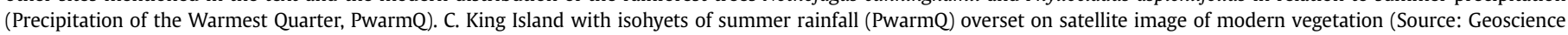
Australia NatMap Raster Premium 2005). D. Local setting of Yarra Creek site. 
contamination of a background-age sample. Wood samples were identified as Nothofagus and Eucalyptus, and a single pollen sample revealed the presence of Nothofagus, Tasmannia, abundant Phyllocladus, some ferns and unidentified angiosperms (Jennings, 1959). D'Costa et al. (1993) described an extended pollen record from Egg Lagoon to the north of Yarra Creek. The sequence included abundant evidence of the former presence of cool-temperate rainforest, but this evidence was all beyond the limit of radiocarbon dating.

\subsection{Climatic setting}

Surrounded by ocean in the middle of Bass Strait, King Island experiences one of the most equable thermal climates in the Australian region with less than $6^{\circ} \mathrm{C}$ difference between mean summer and winter temperatures. The island's winter-dominated rainfall climate (Jun-Aug $40 \%$ of c. $900-1080$ mm MAP) results from the low latitude position of the subtropical high during the cool months; rain bearing fronts associated with the westerly wind-flow bring substantial winter precipitation. However, precipitation is substantially lower during the summer months because the subtropical high is placed over southern Australia meaning rain bearing fronts are further pole-ward.

In terms of synthetic climatic parameters estimated using BIOCLIM (see below) (Houlder et al., 2000), the modern climate of Yarra Creek is summarised in Table 1 and the values for several parameters are plotted in Australian climate space in Fig. 2. The mean annual temperature of $12.9^{\circ} \mathrm{C}$ results from the combination of moderate summers and warm winters (for the latitude), reflecting the strong maritime influence on the climate. This maritime climate is very unusual in relation to the continental climates of the Australian mainland, and even the rest of Tasmania (see Fig. 2). Winter temperatures are very warm in relation to latitudinal gradients and the annual temperature range is about equal to the lowest value for any southern Australian site (Fig. 2c). Mean annual precipitation is estimated to be $1007 \mathrm{~mm}$ : only $140 \mathrm{~mm}$ falls on average over the three summer months. BIOCLIM estimates of the range of annual rainfall values encountered in the Yarra Creek catchment range from 1000 to $1100 \mathrm{~mm}$. A 33 year rainfall record (1974-2007) from the Yarra Creek catchment (inland of the fossil site) yields a mean annual precipitation of $1078 \mathrm{~mm}$, and a summer precipitation of $148 \mathrm{~mm}$ (data provided by Australian Bureau of Meteorology).

\subsection{King Island biota}

Although approximately $70 \%$ of the vegetation of King Island has been cleared for agriculture, mostly during the 20th Century, it is possible to use the current distribution of native vegetation remnants (Barnes et al., 2002) and a 19th Century vegetation map (Campbell, 1888) to make a good reconstruction of pre-European

Table 1

Climatic summary (selected BIOCLIM parameters) for Yarra Creek site.

\begin{tabular}{lll}
\hline Parameter & Abbreviation & Value \\
\hline Mean Annual Temperature & MAT & $12.9^{\circ} \mathrm{C}$ \\
Max. Temperature of Warmest Month & TwarmM & $20.1^{\circ} \mathrm{C}$ \\
Min. Temperature of Coldest Month & TcoldM & $7.2^{\circ} \mathrm{C}$ \\
Temperature Annual Range & Trange & $12.9^{\circ} \mathrm{C}$ \\
Mean Temperature of Warmest Quarter & TwarmQ & $16.0^{\circ} \mathrm{C}$ \\
Mean Temperature of Coldest Quarter & TcoldQ & $10.1^{\circ} \mathrm{C}$ \\
Mean Annual Precipitation (mm) & MAP & 1007 \\
Precipitation of Wettest Month (mm) & PwetM & 133 \\
Precipitation of Driest Month (mm) & PdryM & 38 \\
Precipitation of Warmest Quarter (mm) & PwarmQ & 137 \\
Precipitation of Coldest Quarter (mm) & PcoldQ & 369 \\
\hline
\end{tabular}

vegetation. Most of the island was covered in short or tall heathy vegetation dominated by a diverse sclerophyll flora (especially members of Myrtaceae, Ericaceae, Casuarinaceae, and Proteaceae). The vicinity of the fossil site has the highest rainfall and the least depauperate soils on the island. This region was largely covered in forest dominated by Eucalyptus species, or by Melaleuca ericifolia. Tall eucalypt forest with a closed subcanopy occurred in the most sheltered gullies (e.g. in the Yarra Creek catchment). Cooltemperate rainforest species (e.g. Hedycarya angustifolia, Atherosperma moschatum, treeferns) occur in these very sheltered, moist sites.

In contrast to the well-known vegetation, the insect biota of King Island remains relatively poorly studied (McQuillan, 2003), although the fauna of aquatic habitats, including both streams and wetlands, has recently been surveyed (Davies et al., 2003). The limited extent of 'natural' vegetation means that even today, with extensive collections, we are not able to reliably recreate the former insect diversity of the island in pre-European times. The published King Island terrestrial beetle fauna, based mainly on century old work, amounts to fewer than 350 species (Lea, 1908). This is certainly a significant underestimate of the true diversity, which may have been be several times this number. Modern revisions that include information on taxa occurring on King Island are almost exclusively based on material collected during the late 19th or early 20th centuries (Calder, 1986; Baehr, 1992, 1997, 2004; Britton, 2000).

\section{Methods}

\subsection{Stratigraphy and sampling}

Approximately $10 \mathrm{~m}$ of Quaternary sediments are exposed in the sea cliff section, the base of which is summarised in Fig. 3; the upper seven metres of the sequence, composed of unconsolidated Holocene dune sand, is not shown. The Holocene sands locally and unconformably overly $1.6 \mathrm{~m}$ of "coffee rock", indurated, iron stained sand that represents consolidated aeolian sediments. Underneath the coffee rock, and separated from it by an angular unconformity, are $1.4 \mathrm{~m}$ of inter-bedded sandy peat and organic sands that contain intra-clasts of peat and, occasionally, beachrolled cobbles. The basal sandy peat sits on a distinctive grey clay layer that contains large logs. Samples for analysis of plant macrofossil and insect analysis were recovered from the uppermost $(1.6 \mathrm{~m})$ and lowermost $(2.8 \mathrm{~m})$ exposed sandy peat layers, and samples for pollen analysis from these and several further locations by Jordan and Barnes (see Fig. 3).

\subsection{Thermoluminescence dating}

Previous research, discussed above, suggested that the age of the basal log-bearing grey clays were beyond the limit of the radiocarbon technique. Given that the macrofossil flora contained wet sclerophyll forest or rainforest taxa, it was considered likely that the sediments belonged to the last interglacial (MIS 5e) or another part of MIS 5. To test this assumption, three sand-rich samples were analysed by David Price for thermoluminescence dating potential.

Thermoluminescence ( $\mathrm{TL}$ ) samples were analysed by the combined regenerative and additive method using the 90-125 $\mu \mathrm{m}$ quartz grain size fraction, which was separated from the bulk sample and suitably treated (Nanson et al., 1991). TL measurements were made using an EMI 9635QB photomultiplier fitted with a Corning 7-59 transmitting filter and a Chance Pilkington heat filter. In total 28 sample aliquots were utilised in the analysis of each sample. These were deposited by the volumetric method 

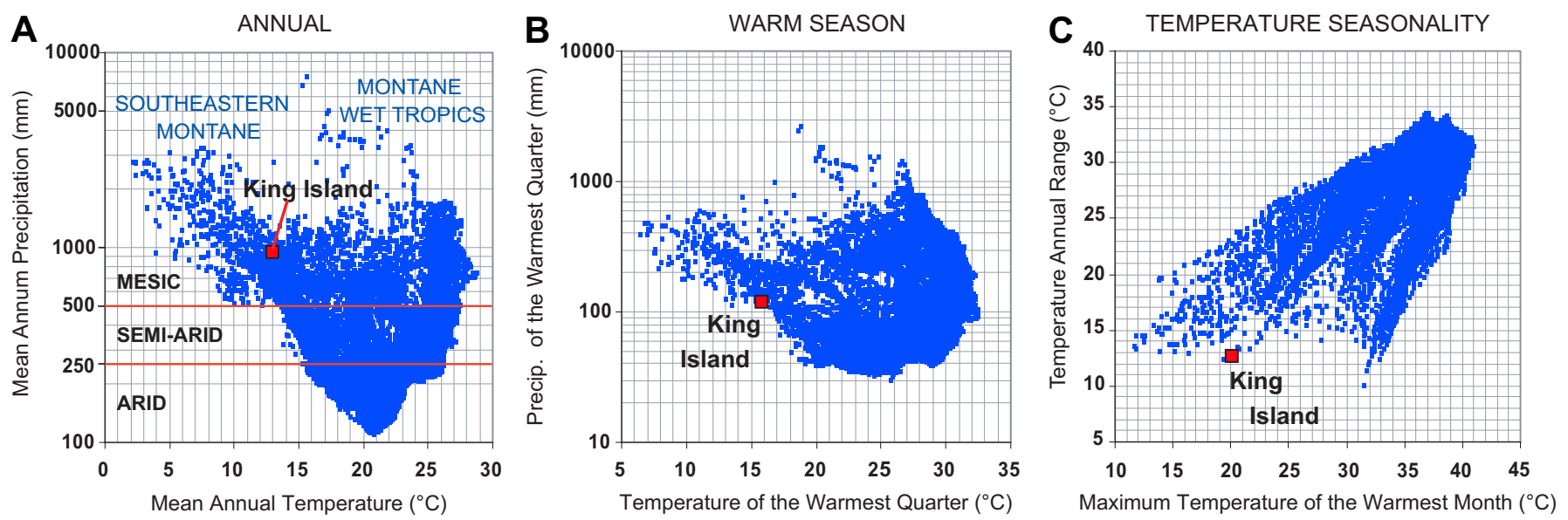

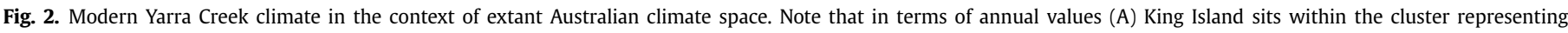

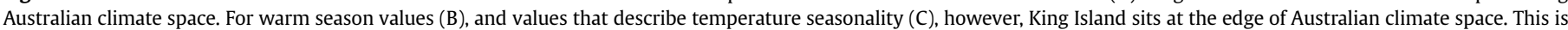

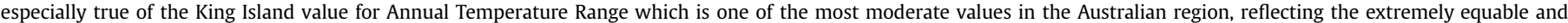
therefore continentally unusual King Island thermal climate (see text).

described by Bell (1978), each aliquot weighing slightly less than $5 \mathrm{mg}$ and reproducible to $2 \%$ at one standard deviation over 200 aliquots. A heating rate of $5{ }^{\circ} \mathrm{C}$ per second was used in the glowout procedure; a 90Sr plaque radiation source was used for TL regeneration and second glow normalisation procedure was applied to all TL data. Calibrated thick source alpha counting was employed in the determination of the sample uranium and thorium specific activity level and the potassium content was measured by atomic emission spectroscopy. A full account of the laboratory method is given by Shepherd and Price (1990) and Nanson et al. (1991).

\subsection{Macrofossil and microfossil analysis}

Samples for macrofossil analysis were excavated from the section in large contiguous blocks that were removed to the laboratory for processing. Macrofossils were recovered by disaggregation of samples using a warm, near-saturated aqueous solution of sodium tetrapyrophosphate and washing through a $730 \mu \mathrm{m}$ (plant parts) or $250 \mu \mathrm{m}$ (insects) sieve. Insect fossils were then extracted using kerosene floatation of the organic sieve residue, detergent washes to remove the kerosene, and storage in $80 \%$ ethanol (Elias, 1994; Porch and Elias, 2000). Identification was by comparison with specimens in the collection of Porch and the Australian National Insect Collection (Canberra). Plant macrofossils were identified by gross morphological and cuticular comparison with material in the collections of the Department of Plant Sciences, University of Tasmania and the Tasmanian Herbarium. Pollen samples were prepared using standard pollen preparation methods and the samples counted by Macphail.

\subsection{Palaeoclimatic reconstruction}

Bioclimatic envelope models were produced from threedimensionally geocoded modern distribution data. These data were

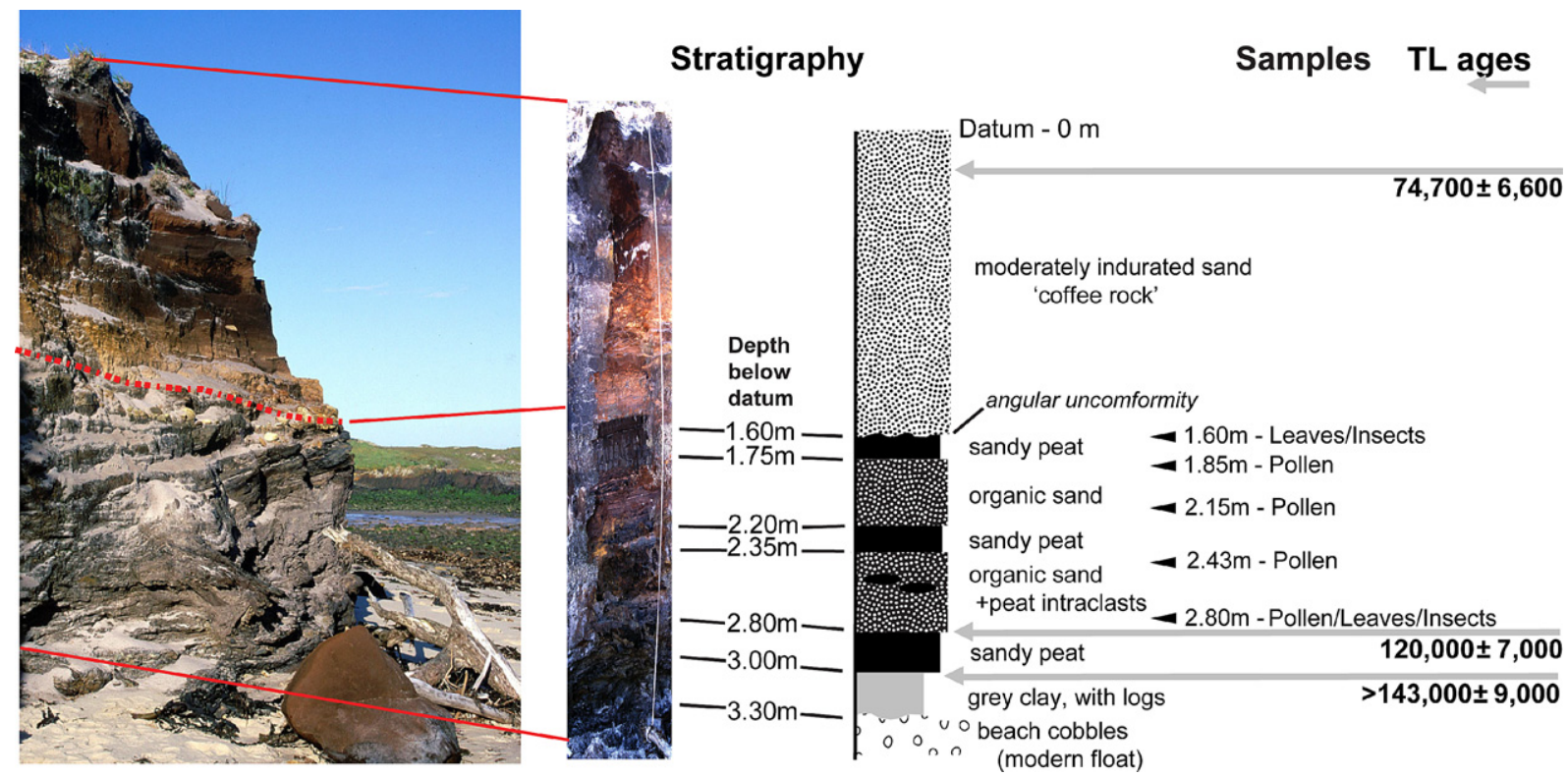

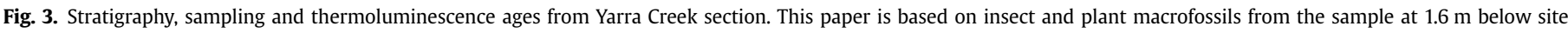
datum. 
derived from published records, museum collections, state government databases and the records of the authors. Bioclimatic envelopes were constructed using BIOCLIM (Houlder et al., 2000). By interrogating synthetic climate surfaces representing average climate for the period 1920-1995, BIOCLIM estimates values for a total of 35 temperature, precipitation, moisture and radiation parameters for each geocoded locality. Here we use a total of six temperature parameters and three precipitation parameters to reflect annual and seasonal climatic variability.

For plant taxa, the large number of distribution records means that the current climatic range of each taxon should be adequately sampled by the bioclimatic envelope model. For beetles, with many fewer records, bioclimatic envelopes almost certainly underestimate the actual climatic range of the taxa. Subsequently, for each taxon the 'raw' BIOCLIM derived values for each parameter are supplemented by an estimate of the probable range of the taxon the estimated parameter range (EPR). The EPR values are based on the relationship between increasing data quality on a parameter's range (maximum-minimum value). For many beetle species several bioclimatic profiles were constructed as increasing amounts of distribution data became available. EPR estimates are based on the range per record value which decreases as sampling quality increases. For a given parameter, the range is the maximum value minus the minimum value, and the range per record value is the range divided by the number of geocoded records contributing to the bioclimatic profile. Jack-knifed tests using 54 modern beetle assemblages from across the Australian continent (Porch, 2007), were used to determine the best function for determining the EPR value. For temperature parameters the EPR range is determined by subtracting four times the range per record value from the raw data bioclimatic profile minimum, and adding the same value to the maximum raw value. An alternative, but similar, approach was applied to precipitation values because distributions of precipitation are often skewed. In this case the minimum estimate represents five times the $0-75$ percentile range per record value, whilst to accommodate the positive skew, the maximum estimate is five times the total range per record value. Given the frequent occurrence of outlier and extreme precipitation values at the high precipitation end of the parameter range it is realistic to consider the maximum precipitation estimate as an indicative rather than absolute value.

Palaeoclimatic reconstruction was accomplished using the coincidence, or parameter overlap, of the climatic requirements of the fossil taxa present in the assemblage (so-called coexistence methods: see, for example Kershaw and Nix (1988), Mosbrugger and Utescher (1997), Marra et al. (2004), Elias (2007), Porch (2007)). For a reconstructed parameter, box-plots summarising the raw bioclimatic data for each taxon contributing to the reconstruction are supplemented by the EPR estimates shown as error bars. The palaeoclimatic estimate is determined from the overlap of the EPR ranges of the taxa in the assemblage: that is, the taxon with the warmest or wettest minimum value determines the minimum value of the estimate range and the taxon with the coldest or driest maximum determines the maximum value.

In modern climate space many parameters are highly correlated at the continental scale meaning a subset of parameters can adequately describe both modern and past climates at this scale. At smaller, more regional scales especially where there is maritime influence, these correlations become weaker. Reconstructions of a relatively large range of temperature and precipitation parameters are presented here for several reasons:

1. To compare the beetle and plant based reconstructions across a range of parameters - the method of palaeoclimatic reconstruction used here was developed and tested only with beetle data;
2. To allow the exploration of palaeoclimatic reconstruction at a place with an unusual modern climate (Yarra Creek) and what this means for interpretation of the results of individual parameter reconstructions.

3. And, to facilitate future comparison with palaeoclimatic reconstructions using different proxies and parameters.

\section{Results}

\subsection{Age of the sequence}

The stratigraphic origin of the TL samples is shown in Fig. 3 and the results summarized in Table 2 . The age shown for sample W3144 ( $>143 \pm 8 \mathrm{ka}$ ) should be regarded as a minimum value having reached an accumulated palaeodose level beyond which no reliable discernible increase in regenerated TL growth could be detected with added laboratory irradiation. Finite ages however were determined for two samples: $120 \pm 7$ ka for sample W3145 and $74.7 \pm 6.6 \mathrm{ka}$ for $\mathrm{W} 3146$. The length of the temperature plateau comparisons at $275-500{ }^{\circ} \mathrm{C}$ in each case lends confidence in the reliability of the TL ages determined (see Price (1994)).

It is likely that the log rich grey clays at the base of the sequence (Fig. 2) represent an environment of deposition markedly different from the overlying peats, and may have been deposited significantly before the peat sequence. The TL age of W3144 (>143 $\pm 8 \mathrm{ka}$ ) implies this may be the case. The age of W3145 (120 $\pm 7 \mathrm{ka})$ from the top of the lower peat layer is entirely consistent with a MIS 5e age. The age of W3146 ( $74.7 \pm 6.6 \mathrm{ka}$ ) from the top of the coffee rock gives a minimum age for the remainder of the organic sediments that unconformably underlie it and implies the sand contributing to the coffee rock accumulated at the beginning of the Last Glacial Stage. There are several lines of evidence that suggest the complete peat sequence, below the unconformity, is last interglacial (MIS 5e) rather than a later substage of MIS 5. These are:

1. The intercalation of peat, sandy peat and sand layers implies active sand movement during the formation of the deposit. We believe it is unlikely that inland dunes would have been active when the regional vegetation consisted of wet sclerophyll

\section{Table 2}

Thermoluminescence results for Yarra Creek samples. Full analytical detail of the palaeodose values and determinations contributing to the final computation of the radiation flux received by each Yarra Creek thermoluminescence sample. Sample ages indicated are corrected for moisture content assuming the 'as collected levels' and a rubidium content of $50 \mathrm{ppm}$ (this makes only a minor contribution to the annual radiation flux received). The cosmic radiation levels indicated are taken from Aitken (1985).

\begin{tabular}{llll}
\hline Sample code & W3144 & W3145 & W3146 \\
\hline Depth $^{\text {a }}(\mathbf{m})$ & 0 & 2.8 & 3.0 \\
Plateau Region (C) & $300-500$ & $275-500$ & $275-500$ \\
Analysis Temp. (C) & 375 & 375 & 375 \\
Palaeodose (Grays) & $>180 \pm 11$ & $80.7 \pm 3.7$ & $59.1 \pm 4.9$ \\
K Content (\% by AES) & $0.500 \pm 0.005$ & $0.295 \pm 0.005$ & $0.380 \pm 0.005$ \\
Rb Content (ppm assumed) & $50 \pm 25$ & $50 \pm 25$ & $50 \pm 25$ \\
Moisture Content (\% by weight) & $13.1 \pm 3$ & $5.8 \pm 3$ & $7.3 \pm 3$ \\
Specific Activity (Bq/kg U + Th) $)^{\mathrm{b}}$ & $38.8 \pm 1.2$ & $13.9 \pm 0.4$ & $14.6 \pm 0.4$ \\
Cosmic Contribution & $107 \pm 25$ & $110 \pm 25$ & $140 \pm 25$ \\
$\quad(\mu G y / y r$ assumed) & & & \\
Annual Radiation Dose ( $\mu$ Gy/yr) & $1258 \pm 57$ & $675 \pm 25$ & $791 \pm 25$ \\
TL Age (ka) & $>143 \pm 9$ & $120 \pm 7$ & $74.7 \pm 6.6$ \\
TL Age range (ka) & $>134$ & $113-127$ & $68.1-81.3$ \\
\hline
\end{tabular}

a Depth is relative to the top of the coffee rock section - see Fig. 3.

b The specific activity of these specimens was measured by means of calibrated thick source alpha counting over a $42 \mathrm{~mm}$ scintillation screen. The values shown assume secular equilibrium for both the $U$ and Th decay chains. The uncertainty levels indicated represent one standard deviation. 
forest and rainforest, vegetation types most characteristic of stable environments. The only likely source of disturbance sufficient to cause active sand movement under such conditions is proximity to the foreshore. Further, it is unlikely that the peat sequence would accumulate over an extended period of MIS 5; if the base of the sequence is last interglacial as the lower peat TL date suggests, it is unlikely the remainder of the peat sequence, beneath the unconformity, is significantly younger. For the remainder of the peat sequence to be much younger the accumulation rate would have to be extremely slow and/or punctuated by significant periods without accumulation. The excellent preservation of the fossil material indicates that the sedimentation rate was rapid and that the peat sequence is not marked by significant time gaps.

2. The elevation of the sequence above present day sea level and its deposition in a terrestrial rather than marine setting (absence of macro and micro marine indicators) implies that deposition may have occurred in a back-dune swamp setting, and environment common along the modern south-eastern Australian coast.

3. The occurrence in the plant record (from upper and lowermost peat samples) of Acacia verticillata var. latifolia, a species that is today exclusively found within the coastal zone, implies the sequence accumulated at the coast and therefore during the last interglacial.

4. The presence of an angular unconformity that separates the peat sequence from the sand above (that dates to latest MIS 5 or early MIS 4), implies that the peat sequence was compacted and then eroded before the sand began to accumulate. This suggests that a significant period, and probably one of lowered sea level, separates the peat sequence from the overlying sand sequence.

5. Finally, the development of rainforest substantially outside its contemporary range, is strongly suggestive of a last interglacial age. In long pollen records from southern Australia the maximum extent of rainforest expansion is during the period inferred to represent the last interglacial.

Integrating the sedimentological, chronological and botanical evidence, the most parsimonious explanation of the depositional environment of the Yarra Creek record is a back-dune swamp, fed by Yarra Creek, behind last interglacial coastal dunes. The height of the sequence above modern sea level, its probable compaction subsequently, absence of salinity indicators in the plant or insect record (in contrast to the deltaic interpretation of Jennings (1959)), and evidence of active sand deposition all support this interpretation. However, the site is inconsistent with maximum sea levels during MIS 5e, which are considered to have been 4-6 $\mathrm{m}$ higher than late Holocene levels (Murray-Wallace, 2002). The simplest interpretation is that the site was deposited during the earliest stages of the last interglacial, after climates had reached full interglacial conditions but before sea level reached its maximum. The date of $120 \pm 7 \mathrm{ka}$ (W3145) for the lower peat layer is consistent with this interpretation, as is evidence that Holocene sea levels in the region did not reach current values until perhaps 6000 years after the establishment of interglacial climates and vegetation (Fleming et al., 1998; Belperio et al., 2002). Hearty et al. (2007) demonstrate that the MIS 5e sea level maximum was similarly preceded by a period (c. $10 \mathrm{ka}$ ) of relatively stable sea level comparable to the modern level or only several metres higher. Under this scenario, the peaty layers (1.6-3.0 m below site datum, Fig. 2) would have been laid down before sea level reached it stage 5e maximum. Subsequent erosion up the upper part of the sequence during the late MIS 5e highstand or during later MIS 5 substages resulted in the formation of the unconformity separating the organic sequence from the sand sequence above. We acknowledge that it is also conceivable, but consider it less likely, for reasons outlined above, that some or all of the sequence accumulated after the last interglacial in one of the substages of MIS 5 that followed the last interglacial.

\subsection{The macrofossil and microfossil record}

The two samples examined for macrofossil biota both contained plant and insect remains. The sample from $1.6 \mathrm{~m}$ was significantly richer in specimens and species; only the results from the analysis of this sample are described here - the overall nature of the taxa present, however, suggests the climate at the time of deposition of both samples was similar. Data on the nature of the plant macrofossil assemblages, and microfossil assemblages are available for comparison with the beetle-based climatic reconstructions and are discussed below. Full details of the composition of the pollen and macrofossil record and their biogeographic significance will be published elsewhere; we here focus on taxa with particular palaeoclimatic significance.

\subsection{Climatic interpretation of the beetle record}

\subsubsection{The assemblage}

A total of 24 beetle taxa from the Yarra Creek assemblage are represented in the 735 bioclimatic profiles for Australian beetles produced specifically for the development and testing of methods for the reconstruction of past climates using fossil beetles (Porch, 2007). Table 3 lists these taxa and the number of records that contribute to their bioclimatic profiles. The assemblage is dominated by taxa that are characteristic of wet sclerophyll forest and rainforest in south-eastern Australia. There are no taxa identified that are rainforest obligates, however, this is not surprising given there are few taxa in south-eastern Australia with such habits: most wet forest taxa occur in both rainforest and wet sclerophyll habitats. The assemblage includes a taxon that has been recorded only from the mainland of Australia (Archaeoglenes australis Lawrence), taxa occurring on the mainland, but with island occurrences in the Bass Strait region (Prostomis cornuta Westwood, Mecyclothorax 'lophoides' Blackburn) and several taxa that are apparent Tasmanian mainland endemics (Orchesia minuta Lea, Ceratognathus westwoodi Thomson). The majority of other taxa occur throughout southeastern Australia in rainforest and wet sclerophyll forest habitats.

\subsubsection{Temperature parameters}

Palaeoclimatic reconstructions for selected BIOCLIM temperature parameters are shown in Figs. 4-6 and the results summarised in Table 4.

4.3.2.1. Mean annual temperature and annual temperature range. Based on the estimated parameter ranges (EPR) of taxa in the assemblage, the estimated Mean Annual Temperature (MAT, Fig. 4a) for the Yarra Creek assemblage is $11.0 \pm 2.3^{\circ} \mathrm{C}$ compared with the modern $12.9^{\circ} \mathrm{C}$; the range of the estimate overlaps with the modern value. The large number of species very close to the upper end of their MAT range suggests that the MAT during deposition of the Yarra Creek assemblage may have been cooler than the present value. It was, however, potentially as warm as present, but not significantly warmer. Estimates also suggest that the Annual Temperature Range (Fig. 4) was substantially enhanced during deposition of the insect assemblage. The median of the beetle reconstructed value of $17.8 \pm 2.1^{\circ} \mathrm{C}$ is $4.9^{\circ} \mathrm{C}$ greater than the current value of $12.9^{\circ} \mathrm{C}$ (Table 4 ). A wide range of beetle taxa represented in the Yarra Creek assemblage have never been collected in regions with a climate as equable as King Island. 
Table 3

List of beetle and plant taxa from the Yarra Creek assemblage contributing to the quantitative palaeoclimatic reconstruction. Code: abbreviation of taxon name. $n$ : number of geocoded records contributing to bioclimatic profile.

\begin{tabular}{|c|c|c|c|c|}
\hline Group & Taxon or Taxa & Code & Family & $n$ \\
\hline Beetle & Saprosites mendax Blackburn & Saprmend & Scarabaeidae & 38 \\
\hline Beetle & Mecyclothorax ‘lophoides’ Blackburn & Mecycord & Carabidae & 20 \\
\hline Beetle & $\begin{array}{l}\text { Trechobembix } b \text {. baldiensis } \\
\text { Blackburn }\end{array}$ & Trecbald & Carabidae & 29 \\
\hline Beetle & $\begin{array}{l}\text { Bembidion jacksoniense Guérin- } \\
\text { Méneville }\end{array}$ & Bembjack & Carabidae & 134 \\
\hline Beetle & $\begin{array}{l}\text { Gymnochthebius australis Blackburn } \\
\text { \& Gymnochthebius setotus Perkins }\end{array}$ & Gymn_ause & Hydraenidae & 203 \\
\hline Beetle & $\begin{array}{l}\text { Simsonia tasmanica Blackburn } \\
\text { \& Simsonia nicholsoni (Carter) }\end{array}$ & SimsoniaL & Elmidae & 20 \\
\hline Beetle & Ceratognathus westwoodi Thomson & Cerowest & Lucanidae & 9 \\
\hline Beetle & $\begin{array}{l}\text { Microsilpha sp.15 (of Thayer, } \\
\text { unpub.) }\end{array}$ & Microsil & Staphylinidae & 60 \\
\hline Beetle & Anepius koebelei Blackburn & Anepkoeb & Staphylinidae & 115 \\
\hline Beetle & Austrorhysus Steel & Austror & Staphylinidae & 100 \\
\hline Beetle & Nargiotes Jeannel & Nargiotes & Leiodidae & 161 \\
\hline Beetle & Neosalpingus Blackburn & Neosalp & Salpingidae & 33 \\
\hline Beetle & Philothermus Aube & Philother & Cerylonidae & 39 \\
\hline Beetle & Aspidophorus humeralis Blackburn & Aspihume & Sphindidae & 41 \\
\hline Beetle & Enicmus Thomson & Enicmus & Latridiidae & 12 \\
\hline Beetle & Cartodere nodifer (Westwood) & Cartnodi & Latridiidae & 38 \\
\hline Beetle & Cartodere bifasciatus (Reitter) & Cartbifa & Latridiidae & 29 \\
\hline Beetle & Orchesia minuta Lea & Orchminu & Melandryidae & 15 \\
\hline Beetle & Pycnomerus fuliginosus Erichson & Pycnfuli & Zopheridae & 48 \\
\hline Beetle & Pycnomerus secutus (Pascoe) & Pycnsecu & Zopheridae & 25 \\
\hline Beetle & Archaeoglenes australis Lawrence & Archaeog & Tenebrionidae & 21 \\
\hline Beetle & Platypus subgranosus (Schedl) & Platsubg & Platypodid & 57 \\
\hline Beetle & Acacicis abundans Lea & Acacabun & Scolytidae & 13 \\
\hline Beetle & Prostomis cornuta Waterhouse & Proscurn & Prostomidae & 13 \\
\hline Plant & $\begin{array}{l}\text { Nothofagus cunninghamii (Hook.) } \\
\text { Oerst. }\end{array}$ & Nothocunn & Nothofagaceae & 299 \\
\hline Plant & $\begin{array}{l}\text { Phyllocladus aspleniifolius (Labill.) } \\
\text { Hook.f. }\end{array}$ & Phylloclad & Podocarpaceae & 106 \\
\hline Plant & Tasmannia lanceolata (Poir.) A.C.Sm. & Tasmlanc & Winteraceae & 866 \\
\hline Plant & $\begin{array}{l}\text { Elaeocarpus reticulatus Smith in } \\
\text { Rees }\end{array}$ & Elaereti & Elaeocarpaceae & 1348 \\
\hline Plant & Melaleuca ericifolia Smith & Melaeric & Myrtaceae & 717 \\
\hline Plant & Monotoca glauca Labill. (Druce) & Monoglau & & 142 \\
\hline Plant & Dicksonia antarctica Labill. & Dicksonia & Dicksoniaceae & 3943 \\
\hline Plant & $\begin{array}{l}\text { Callitris rhomboidea R.Br. Ex Rich. } \\
\text { \& A.Rich. } \\
\text { \& Callitris oblonga A.Rich. \& Rich. }\end{array}$ & Call_obrh & Cupressaceae & 219 \\
\hline
\end{tabular}

Bembidion jacksoniense determines the minimum value of the range (at $15.7-19.8^{\circ} \mathrm{C}$ ); this species is well collected (134 records), common in many riparian and hygrophilic habitats across mainland Australia, and apparently absent from Tasmania.

4.3.2.2. Summer temperatures. Maximum summer temperatures are reconstructed to be significantly warmer than present. Maximum Temperature of the Warmest Month (TmaxM, Fig. 5b) was $2.0^{\circ} \mathrm{C}$ warmer than present (Table 4). The $\pm 1.0^{\circ} \mathrm{C}$ range of the estimate suggests that summer maximum temperatures were certainly warmer than they are today. It is possible that TmaxM has been overestimated. A. australis is the only taxon contributing to the minimum value of the TmaxM range; its exclusion nonetheless would result in an estimate, based on the well collected genus Gymnochthebius that would still range from about the present value $\left(20.1^{\circ} \mathrm{C}\right)$ to $23.1^{\circ} \mathrm{C}$. The elevated estimated value for TmaxM may seem to contradict the Temperature of the Warmest Quarter estimate (Fig. 5a), which suggests average summer temperatures were very similar to modern values (Table 4 ). This can easily be reconciled if the diurnal range was greater than it is today; this would likely be the case under more continental climates than exist on the island presently.
4.3.2.3. Winter temperatures. Winter temperatures are reconstructed to be significantly colder than the present in terms of both Minimum Temperature of the Coldest Month and Temperature of the Coldest Quarter (Fig. 6). The predicted value for Minimum Temperature of the Coldest Month of $2.1^{\circ} \mathrm{C}$ is $5.1^{\circ} \mathrm{C}$ colder than the modern value $\left(7.2^{\circ} \mathrm{C}\right)$, which is still just outside the predicted range of $-0.7-5.0^{\circ} \mathrm{C}$. The predicted mean winter temperature values are likewise significantly cooler than the present day values, although in this case the modern value is just outside the predicted range (see Table 4). Given that Maximum Temperature of the Warmest Month and Temperature of the Coldest Quarter are estimated to be significantly higher and lower, respectively, than modern values, it is not surprising that Annual Temperature Range is predicted to be greater than the present value.

\subsubsection{Precipitation parameters}

Palaeoclimatic reconstructions for the BIOCLIM temperature parameters Mean Annual Precipitation, Precipitation of the Warmest Quarter and Precipitation of the Coldest Quarter are shown in Fig. 7 and the results summarised in Table 5. Reconstructed Mean Annual Precipitation values based on EPR suggest rainfall was $>923 \mathrm{~mm}$, compared with the modern value of $1007 \mathrm{~mm}$; Precipitation of the Warmest Quarter - >172 mm, compared with the modern $137 \mathrm{~mm}$; and, Precipitation of the Coldest Quarter - >252 mm compared with the modern $369 \mathrm{~mm}$. A total of 10 of the 24 taxa in the assemblage used for palaeoclimatic reconstruction have summer rainfall minima that are greater than the modern summer rainfall value of $137 \mathrm{~mm}$ for the site today.

\subsection{Plant record}

\subsubsection{Overview}

The macrofossil record from Yarra Creek is dominated by cooltemperate rainforest and wet sclerophyll forest taxa, especially the rainforest species Nothofagus cunninghamii and Phyllocladus aspleniifolius. Other taxa commonly represented by macrofossils include the treefern Dicksonia antarctica and Elaeocarpus reticulatus (both found in either rainforest or wet eucalypt forests), Eucalyptus $c f$. brookerana, Monotoca glauca and A. verticillata var. verticillata (wet eucalypt forest taxa), the swamp taxon M. ericifolia, and the coastal wattle, A. verticillata var. latifolia. Cypress Pine (Callitris rhomboidea or Callitris oblonga) was found only in the sample from $1.6 \mathrm{~m}$.

The four pollen samples (Fig. 3) indicate the presence of rainforest and wet sclerophyll forest throughout the $1.7 \mathrm{~m}$ of organic sediment. Pollen of the conifer P. aspleniifolius dominates the record (57-67\%), whilst Eucalyptus pollen ranges from (12-19\%). Other well represented taxa include the treeferns Cyathea and $D$. antarctica, several other fern taxa, M. glauca, and N. cunninghamii. Taxa represented consistently by less than $3 \%$ but more than trace amounts include the wet forest/rainforest trees Atherosperma and Elaeocarpus, a range of small tree or shrub taxa including Acacia, Bursaria, Leptospermum, Melaleuca, Pomaderris, Leptecophylla and Tasmannia, and the sedges - Cyperaceae.

\subsubsection{Climatic significance of selected plant taxa}

Several of the plant taxa from the macrofossil assemblage are especially informative regarding the nature of past climates. Climate ranges for seven taxa (Table 3 ) are presented alongside the beetle data in Figs. 4-7. N. cunninghamii has been the focus of a number of studies that have quantified its relationship to climatic and other environmental factors (Busby, 1986, 1987; Lindenmayer et al., 2000). These results have been used to quantify past climates, particularly rainfall, in the Holocene in Victoria (McKenzie and Busby, 1992; McKenzie and Kershaw, 1997). Analysis has suggested 

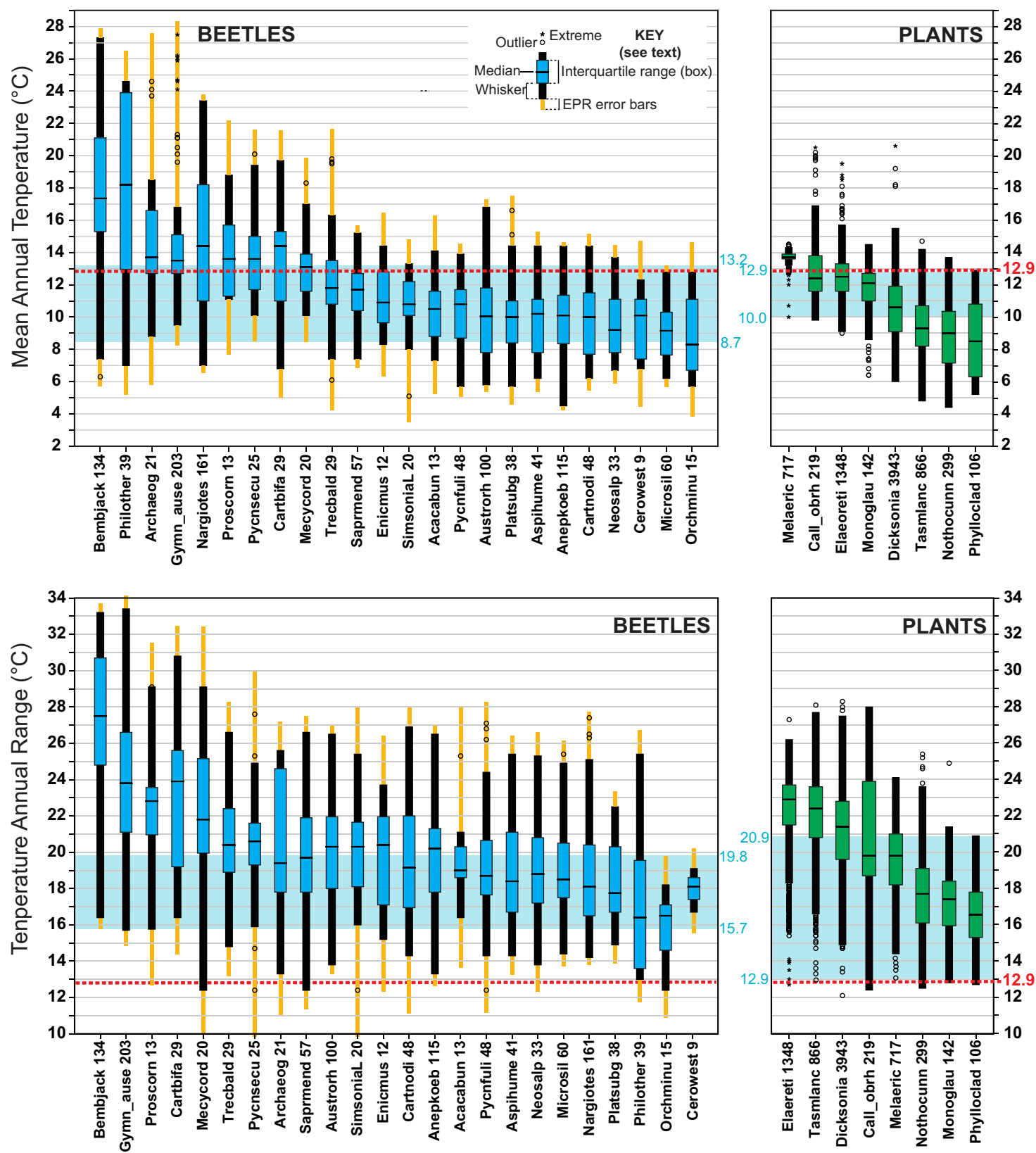

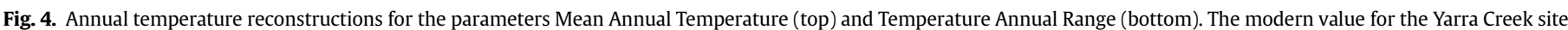

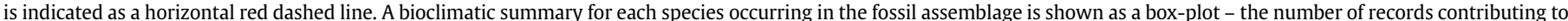

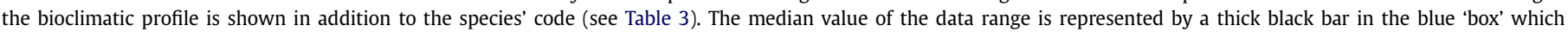

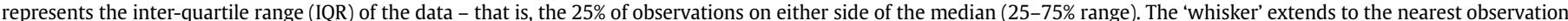

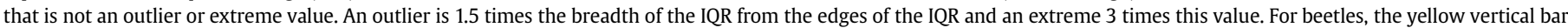

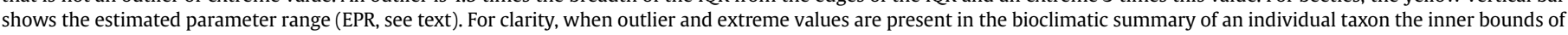

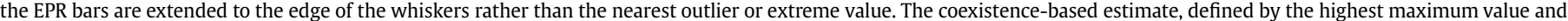
the lowest minimum value, is shown as a transparent blue envelope.

the amount of summer precipitation is a significant limiting factor for N. cunninghamii (Busby, 1986; Lindenmayer et al., 2000) rather than annual rainfall, which extends to a relatively dry $772 \mathrm{~mm}$ in the bioclimatic profile for this taxon. The modern Yarra Creek Precipitation of the Warmest Quarter value of $137 \mathrm{~mm}$ is fractionally drier than the minimum value for $N$. cunninghamii at $138 \mathrm{~mm}$; a value that is attained and substantially exceeded, however, in the catchment of Yarra Creek (Fig. 1).

P. aspleniifolius is a difficult taxon to interpret palaeoclimatically. The probable recent (post-European) occurrence of this species on King Island (Jennings, 1959), indeed its Late Quaternary presence in mainland south-eastern Australia (Churchill and Dodson, 1980; Kershaw et al., 2007), complicates interpretation. Exclusion of the King Island records from the bioclimatic profile of the species increases its summer rainfall minimum from around $137 \mathrm{~mm}$ to $171 \mathrm{~mm}$. It is, nonetheless, like $N$. cunninghamii, indicative of summer rainfall values similar to the present or greater - it is most common in areas where summer and annual rainfall are much greater than on King Island today. The high representation of this species in the pollen record may also be 

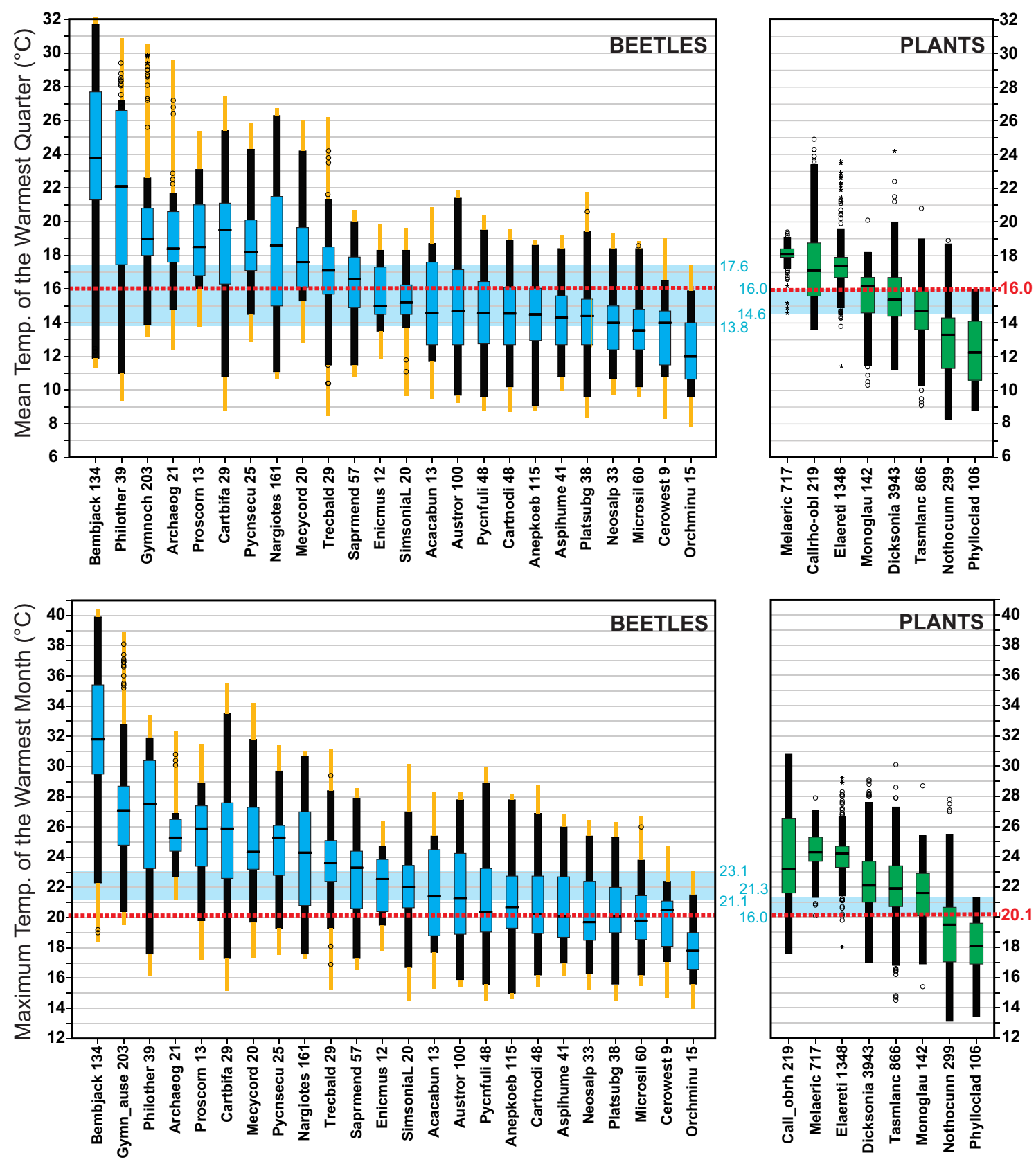

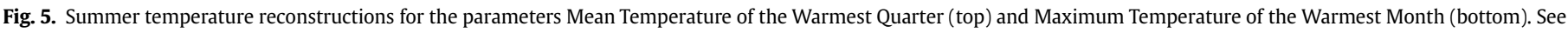
key and caption of Fig. 4 for explanation.

informative. In the south-eastern Australian pollen database (D'Costa and Kershaw, 1997) pollen samples with more than $10 \%$ representation of Phyllocladus are known only from areas with more than $1500 \mathrm{~mm}$ annual rainfall. E. reticulatus and Tasmannia lanceolata have summer precipitation minimum very similar to the modern Yarra Creek value. The range of other temperature and precipitation parameters for these taxa span the modern Yarra Creek values.

\subsection{Climatic summary}

The climatically informative beetle and plant taxa indicate that the Yarra Creek assemblage was deposited under climatic conditions that were substantially wetter than today in terms of summer rainfall and almost certainly wetter annually. The nature of the pollen assemblage, especially the abundance of $P$. aspleniifolius, similarly suggests more summer and annual precipitation. In terms of temperature, there is ambiguous evidence that average summer temperatures may not have been warmer than the present day. This is based on the presence of $P$. aspleniifolius, which must, however, be interpreted cautiously - in modern Tasmanian climate space there are no places that are warmer than the Yarra Creek catchment with the requisite high levels of summer precipitation. Summer thermal climates were certainly, nonetheless, very similar to those of King Island today. Annual temperature is reconstructed to be slightly cooler to equal to the modern value, whereas winter temperatures are reconstructed to be significantly cooler than the modern value. 

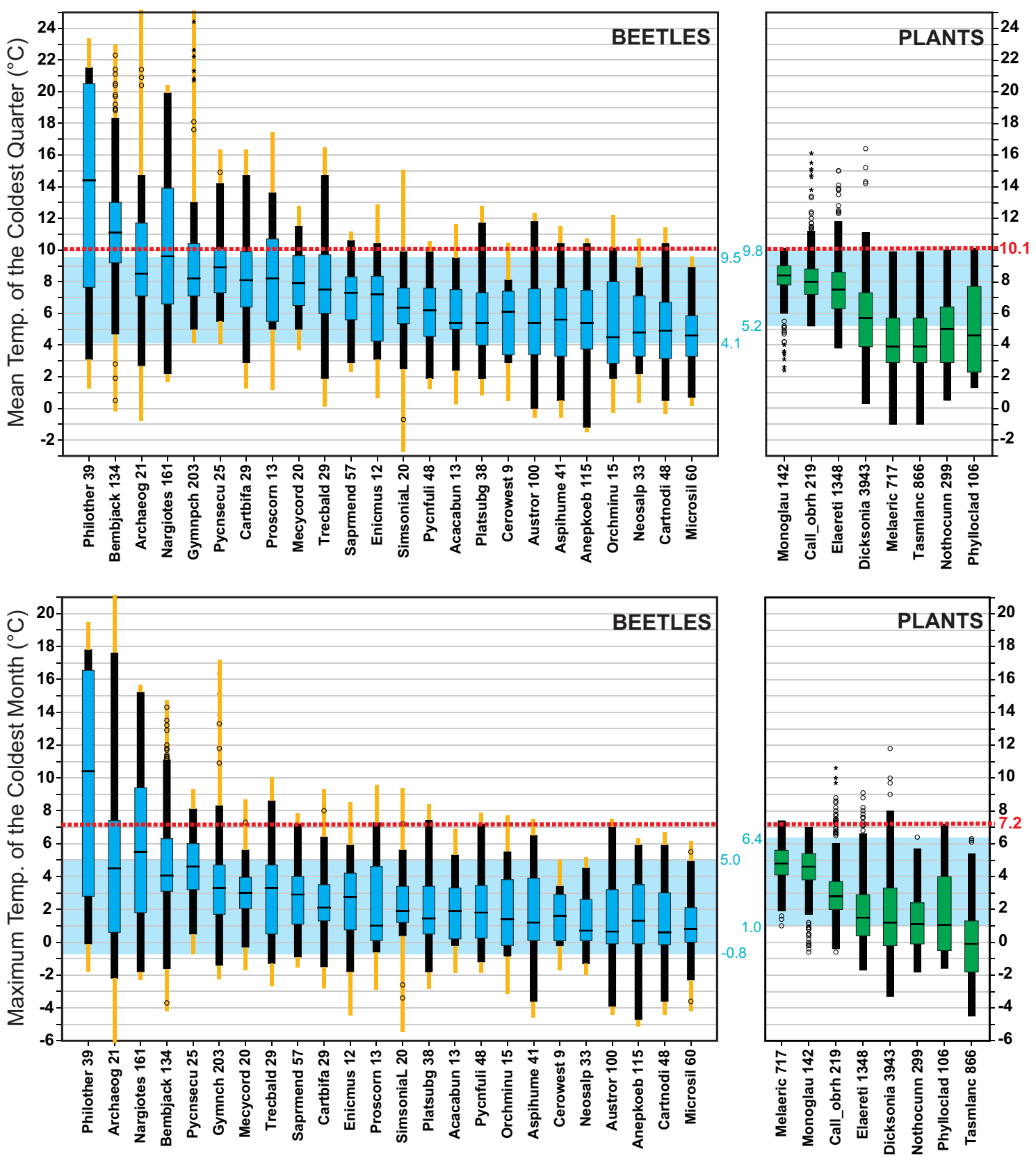

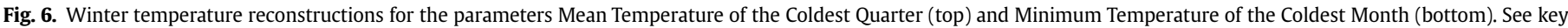
and caption of Fig. 4 for explanation.

\section{Discussion}

\subsection{Increased continentality or climate space artefact?}

The beetle-based reconstructions of the climate at the time of the deposition of the sample from $1.6 \mathrm{~m}$ suggest that at the last interglacial the climate of King Island was substantially different from that of the present day: summer rainfall was higher, and temperature seasonality was greater resulting in hotter summers (warmer maximum temperatures) and colder winters. The plant record is entirely consistent with this reconstruction; indeed several taxa would require elevated of summer rainfall to be present in the Yarra Creek catchment. Some aspects of these reconstructions may, however, be an artefact of the unique nature of the modern King Island environment and, how this uniqueness limits our capacity to reconstruct such climates from bioclimatic envelope data.

It is reasonable to infer that the predictions of summer precipitation and temperature are accurate. There are few conceivable limitations associated with the modern climate space relationships of the taxa present - the possible exception, in regard to P. aspleniifolius, was noted above. However, there are good reasons to be cautious of the accuracy of the estimates of winter temperature and thermal seasonality. King Island today is one of the most equable locations in Australia. This moderates summer and winter temperatures, resulting in very low levels of temperature seasonality. The rarity of such maritime localities in Australian climate space means there are very few, if any, records of beetles (or other biota) from such locations. For this reason it possible that many, even all taxa, in the Yarra Creek assemblage with bioclimatic niche 
Table 4

Modern temperature values for Yarra Creek and predicted values for the MIS 5 beetle and plant assemblages based on the estimated parameter ranges (EPR) for beetles and raw data ranges for plants. The predicted values and their 'errors' have been rounded to the nearest single decimal place. Difference is predicted median minus modern value. Abbreviations: MAT - Mean Annual Temperature; Trange Temperature Annual Range; TwarmQ - Mean Temperature of the Warmest Quarter; TmaxM - Maximum Temperature of the Warmest Month; TcoldQ - Mean Temperature of the Coldest Quarter; TminM - Minimum Temperature of the Coldest Month.

\begin{tabular}{|c|c|c|c|c|}
\hline & Parameter & Modern & Predicted & Difference \\
\hline \multirow[t]{4}{*}{ ANNUAL } & MAT $\left({ }^{\circ} \mathrm{C}\right)$ - Beetles & 12.9 & $11.0 \pm 2.2$ & $-1.9 \pm 2.2$ \\
\hline & MAT $\left({ }^{\circ} \mathrm{C}\right)$ - Plants & & $11.5 \pm 1.5$ & $-1.4 \pm 1.5$ \\
\hline & Trange $\left({ }^{\circ} \mathrm{C}\right)$ - Beetles & 12.9 & $17.8 \pm 2.1$ & $+4.9 \pm 2.1$ \\
\hline & Trange $\left({ }^{\circ} \mathrm{C}\right)$ - Plants & & $16.9 \pm 4.0$ & $+4.0 \pm 4.0$ \\
\hline \multirow[t]{4}{*}{ SUMMER $^{\mathrm{a}}$} & TwarmQ $\left({ }^{\circ} \mathrm{C}\right)$ - Beetles & 16.0 & $15.7 \pm 1.9$ & $-0.3 \pm 1.9$ \\
\hline & TwarmQ $\left({ }^{\circ} \mathrm{C}\right)$ - Plants & & $15.3 \pm 0.7$ & $-0.7 \pm 0.7$ \\
\hline & $\operatorname{TmaxM}\left({ }^{\circ} \mathrm{C}\right)$ - Beetles & 20.1 & $22.1 \pm 1.0$ & $+2.0 \pm 1.0$ \\
\hline & TmaxM $\left({ }^{\circ} \mathrm{C}\right)$ - Plants & & $20.7 \pm 0.6$ & $+0.6 \pm 0.6$ \\
\hline \multirow[t]{4}{*}{ WINTER } & TcoldQ $\left({ }^{\circ} \mathrm{C}\right)$ - Beetles & 10.1 & $6.8 \pm 2.7$ & $-3.3 \pm 2.7$ \\
\hline & TcoldQ $\left({ }^{\circ} \mathrm{C}\right)$ - Plants & & $7.6 \pm 2.4$ & $-2.5 \pm 2.4$ \\
\hline & $\operatorname{Tmin} M\left({ }^{\circ} \mathbf{C}\right)-$ Beetles & 7.2 & $2.1 \pm 2.9$ & $-5.1 \pm 2.9$ \\
\hline & TminM $\left({ }^{\circ} \mathrm{C}\right)$ - Plants & & $3.7 \pm 2.7$ & $-3.5 \pm 2.7$ \\
\hline
\end{tabular}

a In southern Australia the 'Warmest Quarter' is essentially identical to the summer season.

characteristics more continental than King Islands today could actually occur on King Island, or at other very maritime localities. We therefore consider two alternative explanations for the more continental temperature reconstructions presented here: they are artefacts produced by the lack of collecting from equable maritime climates, or they are accurate and reflect increased continentality, possibly due to maritime regression during late stages of MIS 5e or immediately afterward. With a sill depth of $-55 \mathrm{~m}$ (Blom, 1988), King Island would have been an island - or occasionally become an isthmus largely surrounded by sea - during all of MIS 5 (based on sea level data in Lambeck and Chappell (2001)). Given the close proximity of the Yarra Creek site to the sea throughout MIS 5 and, consequentially, the likely maintenance of an equable climate throughout this period, we believe our results are more likely to reflect the lack of modern distribution data from equable regions rather than enhanced seasonality resulting from markedly lowered sea level.

\subsection{Regional significance and comparisons}

Summer temperatures equivalent to the present and elevated summer rainfall is entirely consistent with south-eastern Australian pollen records inferred to cover this period (Harle, 1997; Colhoun et al., 1999; Kershaw and van der Kaars, 2007). The difficulties of dating pollen sequences beyond the radiocarbon barrier (Kershaw et al., 2004), means most records that are believed to be last interglacial, even MIS 5 generally, have inferred chronologies based on ambiguous chronological data (Kershaw, 1976; Colhoun et al., 1989, 1999; D'Costa et al., 1993; Harle et al., 2004). Even so, there are a number of patterns worth examining from the perspective of probable correlations and regional significance of the Yarra Creek record. Because of the difficulties of finding clear temperature indicators in the pollen records, other than suggestions that temperatures were similar to, or potentially slightly warmer than today, much of the following discussion focuses on evidence for moisture regimes.

The pollen record from Egg Lagoon at the northern end of King Island, contains an extended record of Quaternary vegetation change that includes significant quantities Phyllocladus pollen in the middle third of the sequence (D'Costa et al., 1993; D'Costa, 1997). Although Nothofagus is much less well represented it occurs in samples with the highest levels of Phyllocladus representation.
Significantly, the most rainforest rich sample from Egg Lagoon also contains pollen of Callitris (D'Costa et al., 1993), closely paralleling the nature of the Yarra Creek assemblage presented here. It is possible that the peak representation of cool-temperate rainforest taxa at Egg Lagoon represents the same period as the Yarra Creek sequence and reflects the widespread occurrence of cool-temperate rainforest on King Island, at least in the wetter and elevated southern regions. It is also possible, however, that this zone of high rainforest representation predates the last interglacial. Like Egg Lagoon, Pulbeena Swamp in the northwest of Tasmania has an extended pollen record that largely predates 40,000 years (Colhoun et al., 1982). Although Colhoun et al. (1982) argue the sequence spans $65,000+$ years it is likely that the sequence may span the period from the Holocene to MIS 6. Elevated representations relative to the Holocene - of Phyllocladus and Nothofagus occur in the lower half of the record implying more extensive rainforest during the period that probably represents MIS 5.

Lake Selina, in the west coast ranges of Tasmania, has one the best chronologies for long pollen records in the region; the dating in this case is by biostratigraphic comparison with the marine isotope stratigraphy rather than by geochronological means (Colhoun et al., 1999). Here, in the high precipitation, medium altitude $(516 \mathrm{~m})$ ranges of western Tasmania, the representation of cool-temperate rainforest taxa appears to reflect regional climate to the extent that all major stages and substages of the marine isotope record (from MIS 5e) are evident. In the Lake Selina record representation of Phyllocladus reaches its highest levels during the early Holocene and the last interglacial, although substantial quantities are present during MIS 5a and MIS 5c. Nothofagus, in contrast, is similarly abundant during the Holocene and much of MIS 5, although peaking in the last interglacial. Colhoun et al. (1999) note the difficulty of interpreting the climatic significance of the last interglacial assemblage from Lake Selina (in the context cool ever-wet western Tasmania), but do suggest the absence of summer drought, a condition less likely with the elevated summer precipitation values reconstructed for Yarra Creek. In terms of temperature (presumably mean annual temperature) they suggest that the last interglacial temperature was similar to present, and it was cooler in subsequent substages of MIS 5 by $0.6-2.2^{\circ} \mathrm{C}(5 \mathrm{a}, 5 \mathrm{c})$ and $2.2->3.5^{\circ} \mathrm{C}(5 \mathrm{~b}, 5 \mathrm{~d})$ (Colhoun et al., 1999; Table 3).

The marine pollen record of core E55-6, collected from off-shore Victoria, to the northwest of King Island, is well dated using the marine isotope stratigraphy (Harle, 1997). In this record, cooltemperate rainforest taxa (N. cunninghamii, Lagarostrobos franklinii, P. aspleniifolius), are best represented during MIS 5e, and to a lesser extent other MIS 5 substages. Harle (1997) interprets this to reflect high levels of effective precipitation, and suggests most of the rainforest pollen in this marine record was likely to be of Tasmanian origin. Lake Wangoom, on the western Victorian basalt plains of southern Victoria has, like other long terrestrial records from the region, proved difficult to date (Harle et al., 2002, 2004). Like Lake Selina, the chronology is largely derived from the comparison with the marine isotope record (Harle et al., 2004). In the Lake Wangoom record, the greatest representation of rainforest occurs during MIS 5e when both Nothofagus and treeferns (Cyathea, Dicksonia) attain their greatest representation. Harle et al. (2004) argue the expansion these elements reflects substantially elevated levels of effective precipitation. The pollen record from Caledonia Fen, a high altitude ( $1280 \mathrm{~m}$ above sea level) site in eastern Victorian is inferred to extend to MIS 6 (Kershaw et al., 2007). During the last interglacial the vegetation consisted of wet eucalypt forest, with a composition similar to the Holocene, suggesting that temperature and precipitation levels were similar to the present (Kershaw et al., 2007). 


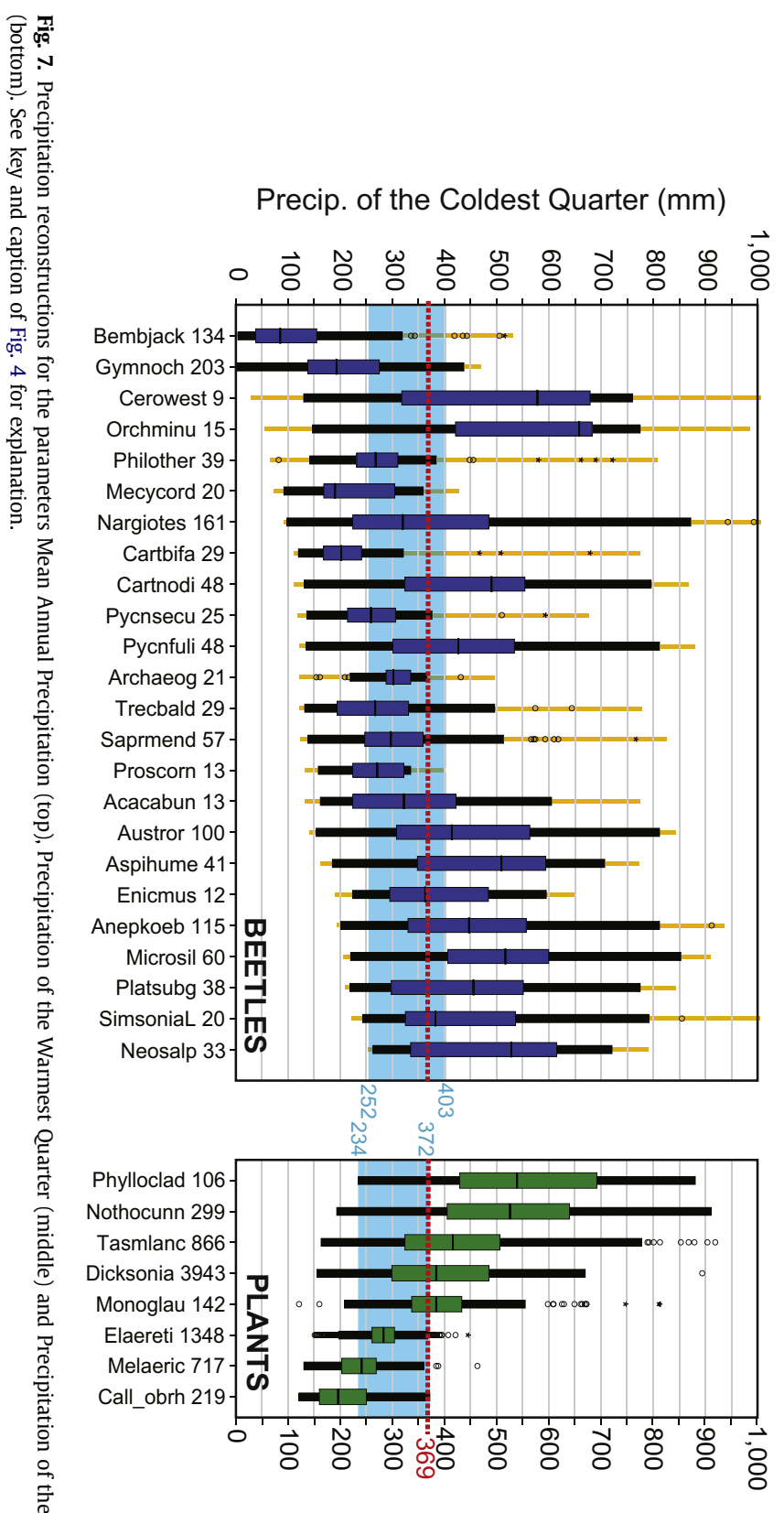

Precipi. of the Warmest Quarter (mm)

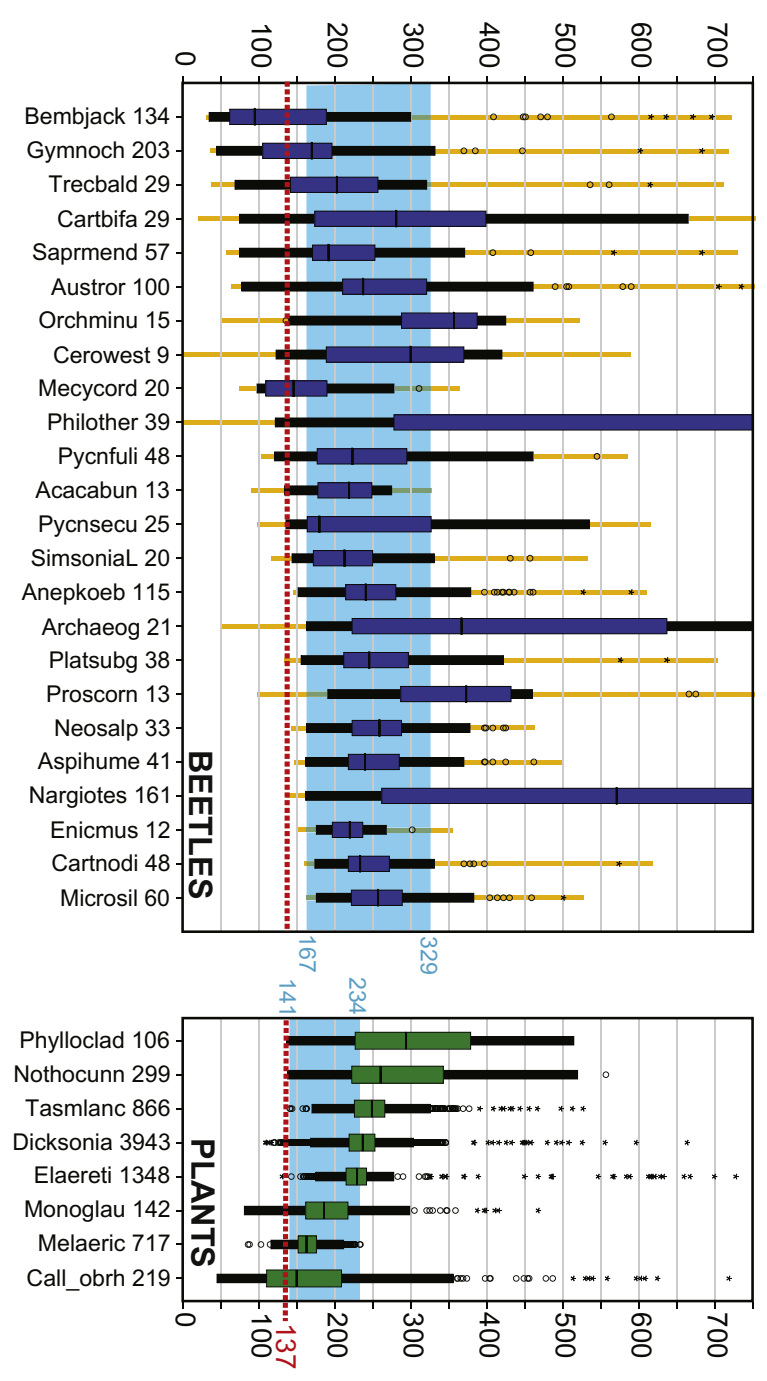

Mean Annual Precipitation (mm)

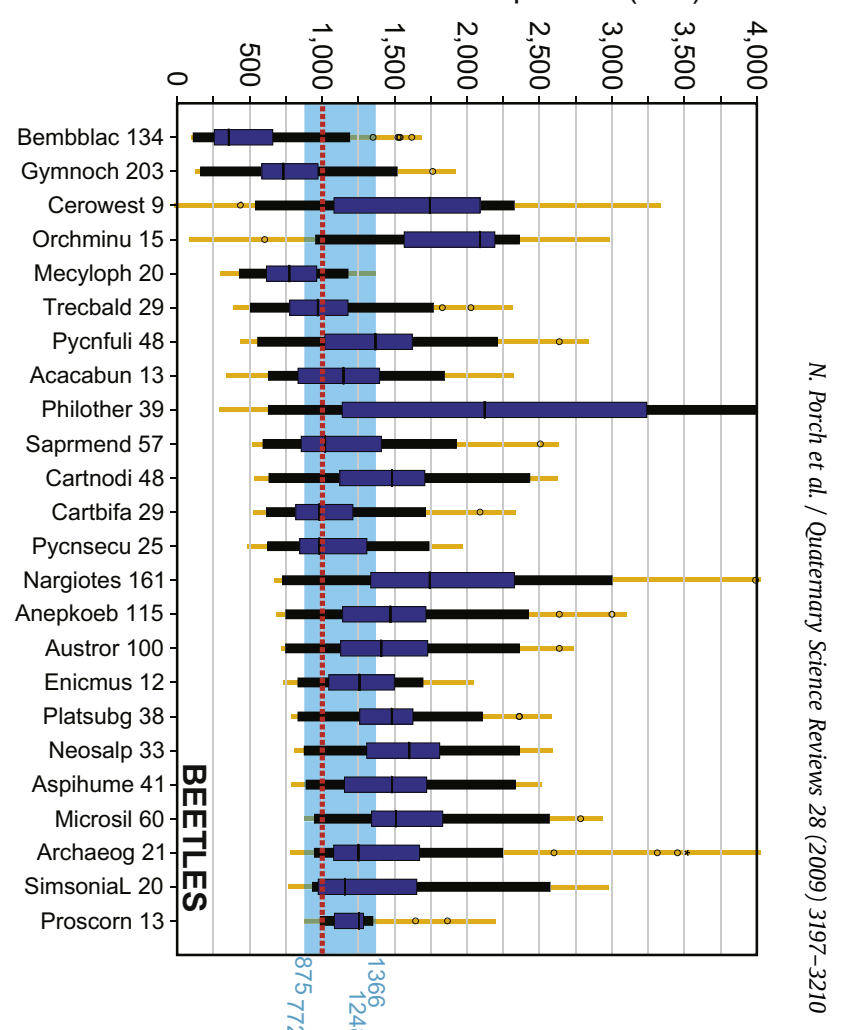

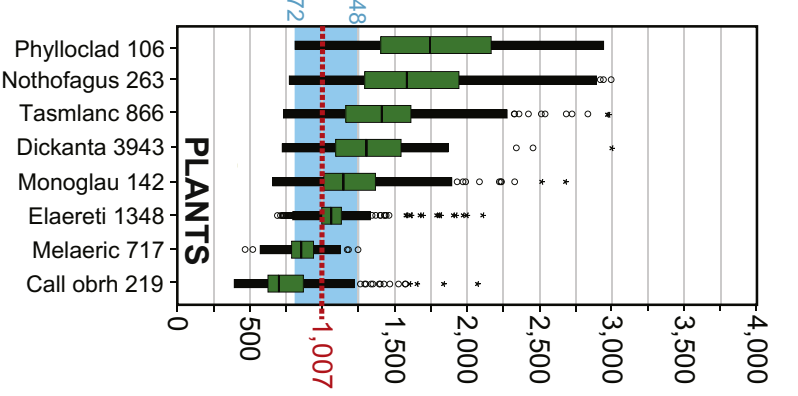


Table 5

Modern precipitation values for Yarra Creek and predicted values for the MIS 5 beetle and plant assemblages based on the estimated parameter ranges (EPR) for beetles and raw data ranges for plants. Abbreviations: MAP - Mean Annual Precipitation; PwarmQ - Precipitation of the Warmest Quarter; PcoldQ - Precipitation of the Coldest Quarter. The predicted minimum represents the minimum estimate for precipitation given the difficulties of accurately predicting the actual precipitation range due to the strong skew of precipitation responses in climate space (see text).

\begin{tabular}{|c|c|c|c|c|}
\hline & Parameter & Modern & Predicted & $\begin{array}{l}\text { Predicted } \\
\text { minimum }\end{array}$ \\
\hline ANNUAL & $\begin{array}{l}\text { MAP }(\mathrm{mm}) \text { - Beetles } \\
\text { MAP (mm) - Plants }\end{array}$ & 1007 & $\begin{array}{l}1065 \pm 114 \\
1059 \pm 189\end{array}$ & $\begin{array}{l}>951 \\
>870\end{array}$ \\
\hline SUMMER $^{\mathrm{a}}$ & $\begin{array}{l}\text { PwarmQ (mm) - Beetles } \\
\text { PwarmQ }(\mathbf{m m}) \text { - Plants }\end{array}$ & 137 & $\begin{array}{l}224 \pm 51 \\
202 \pm 31\end{array}$ & $\begin{array}{l}>172 \\
>171\end{array}$ \\
\hline WINTER & $\begin{array}{l}\text { PcoldQ }(\mathbf{m m}) \text { - Beetles } \\
\text { PcoldQ }(\mathbf{m m}) \text { - Plants }\end{array}$ & 369 & $\begin{array}{l}294 \pm 41 \\
339 \pm 105\end{array}$ & $\begin{array}{l}>252 \\
>234\end{array}$ \\
\hline
\end{tabular}

a In southern Australia the 'Warmest Quarter' is essentially identical to the summer season.

Collectively, pollen-based vegetation reconstructions from south-eastern Australia suggest that the last interglacial was certainly wetter than the present and possibly warmer (Kershaw et al., 2004), although evidence for warmer conditions is at best ambiguous. Pollen-based evidence, however, is subject to the potential influence of Aboriginal burning on the nature of Holocene vegetation, making comparison of the Holocene with previous interglacials somewhat subjective (Kershaw et al., 2002; Harle et al., 2004). The beetle-based data presented here, bolstered by the nature of the associated vegetation and its climatic significance, indicate the regional pollen-based interpretations of increased effective precipitation for MIS 5 are reliable and reflect real differences in the nature of last interglacial climate.

\section{Conclusions}

The Yarra Creek beetle and plant assemblage allowed reconstruction of the past environments and climates on King Island for part of MIS 5. Chronological and other evidence suggests the assemblage was deposited early during MIS 5e, rather than a later MIS 5 substage. The beetle-based results provide the first quantitative climate data from MIS 5 in Australia that is independent of the plant record. These results support the pollen-inferred suggestion that climates during the last interglacial were favourable for the expansion of humid forest types because they were wetter than the Holocene. Finally, the reconstruction of much more continental climates may reflect a methodological artefact; the lack of modern beetle data from extremely equable climates. This situation reinforces the necessity of explicitly considering Quaternary climate reconstructions in the context of modern climate space, particularly in terms of its role in limiting our ability to reconstruct all climates of the past with modern datasets that incompletely sample modern climate space relationships.

\section{Acknowledgments}

We thank Robert Skipworth for access to the site. We also thank the VegTas unit of the Tasmanian Department of Primary Industry, Water and Environment and the Victorian Department of Sustainability and Environment, Australia's Virtual Herbarium, the Australian National Insect Collection (ANIC, Canberra - Tom Weir) and Museum of Victoria for point distribution data and access to collections. Analysis of the insect assemblages was largely carried out whilst Porch was supported by the School of Geography and Environmental Science, Monash University. John Lawrence confirmed the identification of Archaeoglenes australis. We thank two anonymous reviewers for their comments that resulted in a substantially improved paper.

\section{References}

Aitken, M.J., 1985. Thermoluminescence Dating. Academic Press, London.

Baehr, M., 1992. Revision of the Pseudomorphinae of the Australian region: 1. The previous genera Sphallomorpha Westwood and Silphomorpha Westwood: taxonomy, phylogeny, and zoogeography (Insecta, Coleoptera, Carabidae). Spixiana Supplement 18, 1-440.

Baehr, M., 1997. Revision of the Psuedomorphinae of the Australian region. 2. The genera Psudomorpha Kirby, Adelotopus Hope, Cainogenion Notman, Paussotropus Waterhouse, and Cryptocephalomorpha Ritsema: taxonomy, phylogeny, zoogeography. (Insecta, Coleoptera, Carabidae). Spixiana Supplement 23, 1-508.

Baehr, M., 2004. The Amblytelini. A tribe of corticolous ground beetles from Australia. Taxonomy, phylogeny, biogeography. (Coleoptera: Carabidae: Psydrinae). Coleoptera 8, 1-286.

Barnes, R.W., Duncan, F., Todd, C.S., 2002. The Native Vegetation of King Island, Bass Strait, Nature Conservation Report 02/6. Department of Primary Industries, Water and Environment, Hobart.

Bell, W.T., 1978. Studies in Thermoluminescence Dating in Australia. Unpublished PhD thesis. Australian National University.

Belperio, A.P., Harvey, N., Bourman, R.P., 2002. Spatial and temporal variability in the Holocene sea-level record of the South Australian coastline. Sedimentary Geology 150, 153-169.

Blom, W.M., 1988. Late quaternary sediments and sea-levels in Bass Basin, southeastern Australia - a preliminary report. Search 19, 94-96.

Bowler, J.M., Duller, G.A.T., Perret, N., Prescott, J.R., Wyrwoll, K.-H., 1998. Hydrologic changes in monsoonal climates of the last glacial cycle: stratigraphy and luminescence dating of Lake Woods, N.T., Australia. Palaeoclimates 3, 179-207.

Britton, E.B., 2000. A review of Heteronyx Guérin-Méneville (Coleoptera: Scarabaeidae: Melolonthinae). Invertebrate Taxonomy 14, 465-589.

Busby, J.R., 1986. A bioclimatic analysis of Nothofagus cunninghamii (Hook.) Oerst. in southeastern Australia. Australian Journal of Ecology 11, 1-7.

Busby, J.R., 1987. Floristic communities and bioclimates of Nothofagus cunninghamii rainforest in south-eastern Australia. Special Australian Heritage Publication Series Number. In: The Rainforest Legacy. Australian National Rainforest Study, vol. 1. Australian Government Publishing Services, Canberra, pp. 23-31.

Calder, A.A., 1986. Classification, relationships and distribution of the Crepidomeninae (Coleoptera: Elateridae). Australian Journal of Zoology, Supplementary Series $122,1-220$.

Campbell, A.J., 1888. Field naturalist's club of Victoria. Expedition to King Island, November 1887. Official report. The Victorian Naturalist 4, 128-164.

Churchill, D.M., Dodson, J.R., 1980. The occurrence of Phyllocladus aspleniifolius (Labill.) Hook. f. in Victoria prior to 1100 B.P. Muelleria 4, 277-284.

Colhoun, E.A., 1980. Quaternary fluviatile deposits from the Pieman Dam Site, western Tasmania. Proceedings of the Royal Society of London, Series B 207, 355-384.

Colhoun, E.A., 1985. Radiocarbon dates for Tasmania, 1956-1984. Papers and Proceedings of the Royal Society of Tasmania 119, 39-54

Colhoun, E.A., Pola, J.S., Barton, C.E., Heijnis, H., 1999. Late-pleistocene vegetation and climate history of Lake Selina, western Tasmania. Quaternary International 57-58, 5-23.

Colhoun, E.A., Van De Geer, G., Hill, R.S., Bird, T., 1989. Interglacial pollen and plant macrofossils from Langdon River western Tasmania Australia. New Phytologist $111,531-548$

Colhoun, E.A., van de Geer, G., Mook, W.G., 1982. Stratigraphy, pollen analysis and paleoclimatic interpretation of Pulbeena Swamp, northwestern Tasmania. Quaternary Research 18, 108-126.

Croke, J., Magee, J., Price, D., 1996. Major episodes of quaternary activity in the lower Neales River, northwest of Lake Eyre, central Australia. Palaeogeography, Palaeoclimatology, Palaeoecology 124, 1-15.

D'Costa, D., 1997. The reconstruction of Quaternary Vegetation and Climate on King Island, Bass Strait, Australia. Unpublished PhD thesis. Monash University.

D'Costa, D.M., Grindrod, J., Ogden, R., 1993. Preliminary environmental reconstructions from late quaternary pollen and mollusc assemblages at Egg Lagoon, King Island, Bass Strait. Australian Journal of Ecology 18, 351-366.

D’Costa, D.M., Kershaw, A.P., 1997. An expanded recent pollen database from southeastern Australia and its potential for refinement of palaeoclimatic estimates. Australian Journal of Botany 45, 583-605.

Davies, P.E., Brown, K., Walker, R., Cook, L., 2003. The aquatic fauna of King Island's streams and wetlands. In: Donaghey, R. (Ed.), The Fauna of King Island. A Guide to Identification and Conservation Management. King Island Natural Resource Management Group Inc., Currie, King Island, pp. 17-28.

DeVogel, S.B., Magee, J.W., Manley, W.F., Miller, G.H., 2004. A GIS-based reconstruction of late Quaternary paleohydrology: Lake Eyre, arid central Australia. Palaeogeography, Palaeoclimatology, Palaeoecology 204, 1-13.

Elias, S.A., 1994. Quaternary Beetles and Their Environments. Smithsonian Institution Press, Washington.

Elias, S.A., 2007. Beetle records: overview. In: Elias, S.A. (Ed.), Encyclopedia of Quaternary Science, vol. 1. Elsevier, Amsterdam, pp. 151-163.

Fleming, K., Johnston, P., Zwartz, D., Yokoyama, Y., Lambeck, K., Chappell, J., 1998. Refining the eustatic sea-level curve since the Last glacial maximum using far and intermediate-field sites. Earth and Planetary Science Letters 163, 327-342. 
Harle, K.J., 1997. Late Quaternary vegetation and climate change in southeastern Australia: palynological evidence from marine core E55-6. Palaeogeography, Palaeoclimatology, Palaeoecology 131, 465-483.

Harle, K.J., Heijnis, H., Chisari, R., Kershaw, A.P., Zoppi, U., Jacobsen, G., 2002. A chronology for the long pollen record from Lake Wangoom, western Victoria (Australia) as derived from Uranium/Thorium disequilibrium dating. Journal of Quaternary Science 17, 707-720.

Harle, K.J., Kershaw, A.P., Clayton, E., 2004. Patterns of vegetation change in southwest Victoria (Australia) over the last two glacial/interglacial cycles: evidence from Lake Wangoom. Proceedings of the Royal Society of Victoria 116, 105-137.

Hearty, P.J., Hollin, J.T., Neumann, A.C., O'Leary, M.J., McCulloch, M., 2007. Global sealevel fluctuations during the last interglaciation (MIS 5e). Quaternary Science Reviews 26, 2090-2112.

Hesse, P.P., Magee, J.W., van der Kaars, S., 2004. Late quaternary climates of the Australian arid zone: a review. Quaternary International 118-119, 87-102.

Hope, G., Kershaw, A.P., van der Kaars, S., Xiangjun, S., Liew, P.M., Heusser, L.E., Takahara, H., McGlone, M., Miyoshi, N., Moss, P.T., 2004. History of vegetation and habitat change in the Austral-Asian region. Quaternary International 118-119, 103-126.

Houlder, D.J., Hutchinson, M.F., Nix, H.A., McMahon, J.P., 2000. Anuclim v. 5.1. Centre for Resource and Environmental Studies. Australian National University, Canberra.

Jennings, J.N., 1957. Coastal dune lakes as exemplified from King Island, Tasmania. Geographic Journal 123, 59-70.

Jennings, J.N., 1959. The coastal geomorphology of King Island, Bass Strait, in relation to changes in the relative level of land and sea. Records of the Queen Victoria Museum, Launceston, New Series 11, 1-39.

Kershaw, A.P., 1976. A late pleistocene and Holocene pollen diagram from Lynch's Crater, north-eastern Queensland, Australia. New Phytologist 77, 469-498.

Kershaw, A.P., 1978. Record of the last interglacial-glacial cycle from northeastern Queensland. Nature 272, 159-161.

Kershaw, A.P., Clark, J.S., Gill, A.M., 2002. A history of fire in Australia. In: Bradstock, R., Williams, J.W., Gill, A.M. (Eds.), Flammable Australia: the Fire Regimes of Biodiversity. Cambridge University Press, Cambridge, pp. 3-25.

Kershaw, A.P., D'Costa, D.M., Tibby, J., Wagstaff, B.E., Heijnis, H., 2004. The last million years around Lake Keilambete, western Victoria. Proceedings of the Royal Society of Victoria 116, 93-104.

Kershaw, A.P., McKenzie, G.M., McMinn, A., 1993. A quaternary vegetation history of northeastern Queensland from pollen analysis of ODP site 820. Proceedings of the Ocean Drilling Program, Scientific Results 133, 107-114.

Kershaw, A.P., McKenzie, G.M., Porch, N., Roberts, R.G., Brown, J., Heinjis, H., Orr, M.L., Jacobsen, G., Newall, P.R., 2007. A high resolution record of vegetation and climate through the last glacial cycle from Caledonia Fen, southeastern highlands of Australia. Journal of Ouaternary Science 22, 481-500.

Kershaw, A.P., Moss, P., Wild, R., 2005. Patterns and causes of vegetation change in the Australian Wet Tropics region of the last 10 million years. In: Bermingham, E., Dick, C.W., Moritz, C. (Eds.), Tropical Rainforests: Past, Present and Future. University of Chicago Press, Chicago, pp. 374-400.

Kershaw, A.P., Nix, H.A., 1988. Quantitative palaeoclimatic estimates from pollen data using bioclimatic profiles of extant taxa. Journal of Biogeography 15, 589-602.

Kershaw, A.P., van der Kaars, S., 2007. Pollen records, late pleistocene: Australia and New Zealand. In: Elias, S.A. (Ed.), "Encyclopedia of Quaternary Science.". Elsevier, Amsterdam, pp. 2613-2623.

Lambeck, K., Chappell, J., 2001. Sea level change through the last glacial cycle. Science 272, 679-686.

Lea, A.M., 1908. Coleoptera of King Island. Proceedings of the Royal Society of Victoria 20, 143-207.
Lindenmayer, D.B., Mackey, B.G., Cunningham, R.B., Donnelly, C.F., Mullen, I.C. McCarthy, M.A., Gill, A.M., 2000. Factors affecting the presence of the cool temperate rain forest tree myrtle beech (Nothofagus cunninghamii) in southern Australia: integrating climatic, terrain and disturbance predictors of distribution patterns. Journal of Biogeography 27, 1001-1009.

Magee, J.W., Bowler, J.M., Miller, G.H., Williams, D.L.G., 1995. Stratigraphy, sedimentology, chronology and palaeohydrology of quaternary lacustrine deposits at Madigan Gulf, Lake Eyre, South Australia. Palaeogeography, Palaeoclimatology, Palaeoecology 113, 3-42.

Marra, M.J., Smith, E.G.C., Shulmeister, J., Leschen, R., 2004. Late Quaternary climate change in the Awatere Valley, South Island, New Zealand using a sine mode with a maximum likelihood envelope on fossil beetle data. Quaternary Science Reviews 23, 1637-1650.

McKenzie, G.M., Busby, J.R., 1992. A quantitative estimate of Holocene climate using a bioclimatic profile of Nothofagus cunninghamii (Hook.) Oerst. Journal of Biogeography 19, 531-540.

McKenzie, G.M., Kershaw, A.P., 1997. A vegetation history and quantitative estimate of Holocene climate from Chapple Vale, in the Otway region of Victoria, Australia. Australian Journal of Botany 45, 565-581.

McQuillan, P., 2003. Invertebrates on King Island. In: Donaghey, R. (Ed.), The Fauna of King Island. A Guide to Identification and Conservation Management. King Island Natural Resource Management Group Inc., Currie, King Island, pp. 29-36.

Mosbrugger, V., Utescher, T., 1997. The coexistence approach - a method for quantitative reconstructions of Tertiary terrestrial palaeoclimate data using plant fossils. Palaeogeography, Palaeoclimatology, Palaeoecology 134, 61-86.

Moss, P.T., Kershaw, A.P., 2000. The last glacial cycle from the humid tropics of northeastern Australia: comparison of a terrestrial and marine record. Palaeogeography, Palaeoclimatology, Palaeoecology 155, 155-176.

Murray-Wallace, C., 2002. Pleistocene coastal stratigraphy, sea-level highstands and neotectonism of the southern Australian passive continental margin-a review. Journal of Quaternary Science 17, 469-489.

Nanson, G.C., Price, D.M., Young, R.W., Short, S.A., Jones, B.G., 1991. Comparative uranium-thorium and thermoluminescence chronologies for weathered alluvial sequences in the seasonally dry tropics of Northern Queensland, Australia. Quaternary Research 36, 347-366.

Porch, N., 2007. Beetle records: Late Pleistocene of Australia. In: Elias, S.A. (Ed.) Encyclopedia of Quaternary Science, vol. 1. Elsevier, Amsterdam, pp. 179-190.

Porch, N., Elias, S., 2000. Quaternary Beetles: a review and issues for Australian studies. Australian Journal of Entomology 39, 1-9.

Price, D.M., 1994. TL dating of fluvial quartz sands: a comparison of ages obtained at $325^{\circ} \mathrm{C}$ and $375^{\circ} \mathrm{C}$. Ancient TL 12, 20-23.

Shepherd, M.J., Price, D.M., 1990. Thermoluminescence dating of late quaternary dune sand, Manawata/Horowhenua area, New Zealand: a comparison with $14 \mathrm{C}$ age determinations. New Zealand Journal of Geology and Geophysics 33 , 535-539.

Singh, G., Geissler, E.A., 1985. Late Cainozoic history of vegetation, fire, lake levels and climate at Lake George, New South Wales, Australia. Philosophical Transactions of the Royal Society of London, Series B 311, 379-447.

van der Kaars, S., De Deckker, P., Gingele, F.X., 2006. A 100,000-year record of annual and seasonal rainfall and temperature for northwestern Australia based on a pollen record obtained offshore. Journal of Quaternary Science 21, 879-889.

van der Kaars, S., Wang, X., Kershaw, P., Guichard, F., Setiabudi, D.A., 2000. A late quaternary palaeoecological record from the Banda Sea, Indonesia: patterns of vegetation, climate and biomass burning in Indonesia and northern Australia. Palaeogeography, Palaeoclimatology, Palaeoecology 155, 135-153. 